\title{
Ботанічна бібліографія
}

\section{Recent literature of bryophytes in Ukraine (2011-2015)}

\author{
MYKHAILO FEDOSIYOVYCH BOIKO \\ VITALIY MYKHAILOVYCH VIRCHENKO \\ OXANA VACYLIVNA LOBACHEVSKA
}

\author{
BOIKO M.F., VIRCHENKO V.M., LOBACHEVSKA O.V. (2017). Recent literature of \\ bryophytes in Ukraine (2011-2015). Chornomors'k. bot. z., 13 (3): 345-361. \\ doi:10.14255/2308-9628/17.133/9.
}

БАИК О.Л. (2013). Адаптация мха Bryum caespiticium Hedw. к абиотическим стрессовым факторам. Инноваџионные направления современной физиологии растений: мат-ль Всерос. науч. конф. с междунар. уч., Москва, Россия, 2-6 июня 2013 г.: 239.

БАИК О.Л. (2015). Физиолого-биохимические реакции мхов на гипертермию. Бриология: традиции и современность: Сб. статей по мат-лам Междунар. бриолог. конф., посв. 100-летию со дня рожд. А. Л. Абрамовой, Россия, Санкт-Петербург, 12-16 октября 2015 г.: 23-27.

БАїк О.Л. (2011). Мінливість ізоформ пероксидази домінантних видів мохів на техногенних територіях сірчаного видобутку. Відновлення порушених природних екосистем: матер. IV міжнар. наук. конф., Донеиьк, 18-21 жовтня 2011 р.: 36-37.

БАїк О.Л. (2012). Біохімічна мінливість моху Bryum caespiticium Hedw. під впливом абіотичних факторів на посттехногенних територіях сірчаного видобутку. Наукові основи збереження біотичної різноманітності, 3 (10): 183-190.

БАїк О.Л. (2012). Вивчення фізіолого-біохімічної мінливості моху Amblystegium serpens (Hedw.) Schimp. під дією важких металів. Чорноморськ. бот. ж., 8 (2): 134-141.

БАїк О.Л. (2012). Порівняльний аналіз фотосинтетичної активності Bryum caespiticium Hedw. IV відкритий з '̈зд фітобіологів Причорномор'я, присвячений ювілею професора М.Ф.Бойка: зб. тез доп., Херсон, 19 січня 2012 р.: 11.

БАїк О.Л. (2012). Роль мохів у грунтотвірних процесах на територіях сірчаного видобутку. Рекультивація складних техноекосистем у новому тисячолітті: ноосферний аспект: мат-ли міжнар. наук.практ. конф., Дніпропетровськ, 29-30 травня 2012 р.: 290-291.

БАЇк О.Л. (2013). Активність та електрофоретичний спектр ферментів-антиоксидантів мохів за дії металевого стресу. Рослини та урбанізація: матер. III Міжнар. наук.-практ. конф., Дніпропетровськ, 19-20 березня 2013 р.: 93-95.

БАїк О.Л. (2013). Дослідження впливу водного дефіциту на функціональний стан ДНК у моху Bryum caespiticium Hedw. 3 території ПЗ «Розточчя» та сірчаного видобутку. V відкритий з’ізд фітобіологів Причорномор'я: зб. тез доп., Херсон, 25 квітня 2013 р.: 8.

БАїк О.Л. (2014). Внутрішньовидова мінливість листяних мохів. Актуальні проблеми медицини, фармації та біології, 1: 16-32.

БАЇк О.Л. (2014). Вплив гіпертермії на активність та термостабільність пероксидази деяких видів мохів. Відновлення порушених природних екосистем: матер. V Міжнар. наук. конф., Донецьк, 12-15 травня 2014 р.: 367-368.

БАЇк О.Л. (2014). Зміни біохімічних параметрів Bryum caespiticium Hedw. під дією абіотичних факторів на посттехногенних територіях сірчаного видобутку. Інтродукиія, збереження та моніторинг рослинного різноманіття: матеріали Міжнар. наук. конф., присвяченій 175-річчю Ботанічного саду імені акад. О.В. Фоміна Київського нац. ун-ту ім. Т. Шевченка, Київ, 20-24 травня 2014 р.: 164.

БАїк О.Л. (2014). Морфофізіологічні та біохімічні зміни в гаметофіті моху під дією важких металів. Прачі Наукового товариства ім. Шевченка. Екологічний збірник, 39: 210-217.

БАЇк О.Л. (2015). Зміна біохімічних параметрів Barbula unguiculata Hedw. і Bryum caespiticium Hedw. під впливом гіпертермії на посттехногенних територіях видобутку сірки. Наукові основи збереження біотичної різноманітності, 6 (13): 277-292.

БАЇК О.Л., КИЯК Н.Я. (2011). Особливості фотосинтетичної системи домінантних видів мохів на техногенних територіях сірчаного виробництва. XIII з ’̈ззд Укр. ботан. тов-ва: матер. з '̈ззуд, Львів, 19-23 вересня 2011 р.: 409.

(C) Boiko M.F., Virchenko V.M., Lobachevska O.V.

Чорноморськ. бот. ж., 13 (3): 345-361. 
БАРСУКОВ А.А. (2013). К вопросу об охране мохообразных в Харьковской области: теория и практика. Актуальные проблемы изучения и сохранения фито- и микобиоты: Сб. статей II междунар. науч.-практ. конф., Минск, 12-14 ноября 2013 г.: 181-183.

БАРСУКОВ О.О. (2012). Історія вивчення бріофлори Харківщини. Актуальні проблеми ботаніки та екології: мат-ли міжнар. конф. молодих учених, Ужгород, 19-23 вересня 2012 р.: 17-19.

БАРСуКОВ О.О. (2013). Матеріали до бріофлори північного сходу Харківської області. Чорноморськ. бот. ж., 9 (3): 403-415.

БАРСУКОВ О.О. (2014). Бріофлора урбанізованих територій Харківської області. Чорноморськ. бот. ж., 10 (3): 305-321.

БАРСУКОв О.О. (2014). Епіфітні мохоподібні м. Харкова. Укр. бот. журн., 71 (2): 214-222.

БАРСУКОВ О.О. (2014). Мохоподібні заболочених місцезростань Харківщини. VI Ботанічні читання пам’яті Й.К. Пачоського: зб. тез доп. міжнар. наук. конф., Херсон, 19-22 травня 2014 р.: 2223.

БАРСУКОВ О.О. (2015). Види бріофітів, що пропонується включити до «Червоного списку» Харківської області. VI відкритий з 'їзд фітобіологів Причорномор'я: зб. тез доп., Херсон - Лазурне, 19 травня 2015 р.: 9-11.

БАРСУКОВ О.О. (2015). Локально рідкісні бріофіти Харківщини, їх особливості та стан охорони. Чорноморськ. бот. ж., 11 (1): 57-72.

БАРСукОВ О.О. (2015). Мохоподібні Харківської області: автореф. дис. ... канд. біол. наук: спец. 03.00 .05 «Ботаніка». Київ, 2015. 22 с.

БАРСУКОВ О.О., ВІРЧЕНКО В.М. (2012). Myrinia pulvinata (Wahlenb.) Schimp. (Amblystegiaceae) - новий вид і рід для бріофлори України. Укр. бот. журн., 69 (6): 880-885.

БЕСПАЛОВА С.В., ГОРЕЦЬКИЙ О.С., ГЛУХОВ О.З., ЗЛОТІН О.З., МАКСИМОВИЧ В.О., ГОВТА М.В., ЛЯЛЮК Н.М., МАРКІНА Т.Ю., МАСЛОДУДОВА К.М., МАШТАЛЕР О.В., САФОНОВ А.І., ФЕДОТОВ О.В., ШтІРЦ А.Д. (2011). Критерії оцінки екологічного стану середовища за порогами чутливості біоіндикаторів. Проблеми екологї̈ та охорони природи техногенного регіону, 1 (11): $25-44$.

БЕСПАЛОВА С.В., ГОРЕЦЬКИЙ О.С., ЗЛОТІН О.З., МАКСИМОВИЧ В.О., ГОВТА М.В., ЛЯЛЮК Н.М., МАРКІНА Т.Ю., МАСЛОДУДОВА К.М.,. МАШТАЛЕР О.В., САФОНОВ А.І., ФЕДОТОВ О.В., ШТІРЦ А.Д. (2012). Визначення нормованих параметрів біоіндикаторів для екологічного моніторингу. Проблеми екології та охорони природи техногенного регіону, 1 (12): 41-56.

БЕШЛЕЙ С.В., СОХАНЬЧАК Р.Р. (2014). Сезонні зміни вмісту фенолів і активності поліфенолоксидази в гаметофіті Ceratodon purpureus (Hedw.) Brid. та Bryum argenteum Hedw. за умов росту на відвалі шахти "Надія" (Львівська обл.). Інтродукція, збереження та моніторинг рослинного різноманіття: матеріали Міжнар. наук. конф., присвяченій 175-річчю Ботанічного саду імені акад. О.В. Фоміна Київського національного університету ім. Тараса Шевченка, Киї, 20-24 травня 2014 р.: 165-166.

БЕШЛЕЙ С.В., СОХАНЬЧАК Р.Р., ЛОБАЧЕВСЬКА О.В., КАРПІНЕЦЬ Л.І. (2015). Вміст фенОЛів і активність поліфенолоксидази в гаметофіті Ceratodon purpureus (Hedw.) Brid. та Bryum argenteum Hedw. за умов росту на відвалі шахти «Надія». Вісник Львівського ун-ту. Серія Біологія, 69: 256-264.

БІльСьКА І., МАмчУр 3. (2012). Мохи центральної частини міста Івано-Франківська. Молодь $i$ постуn біології: зб. тез VІІІ Міжнародної конф. студентів та аспірантів, Львів, 3-6 квітня 2012 р.: 95.

БІльСьКА І.Я., МАмчур 3.І. (2011). Історія бріофлористичних досліджень території Львівщини. Матер. ХІІІ з '̈зду Укр. ботан. тов-ва, Львів, 19-23 вересня 2011 р.: 260.

Бойко І.В. (2015). Морфо-фізіологічні аспекти стійкості мохів до висушування. Наукові основи збереження біотичної різноманітності: матеріали I (XII) Міжнар. наук. конф. молодих учених, Львів, 21-22 травня 2015 р.: 157-160.

БОЙКО І.В., ЛОБАЧЕВСьКА О.В. (2014). Фізіолого-біохімічні реакції бріофітів на дегідратацію та регідратацію. Стан і біорізноманіття екосистем Шацького природного парку: матеріали наук. конф., Шаџьк, 11-14 вересня 2014 р.: 13.

Бойко М.Ф. (2011). Анотований список мохоподібних Лівобережного Полісся (Україна). Чорноморськ. бот. ж., 7 (2): 144-187.

Бойко М.Ф. (2011). Несудинні рослини (водорості, мохоподібні). Лабораторний практикум: Навч. посібник. Херсон, 2011. 32 с.

Бойко М.Ф. (2012). Доповнення до Чекліста мохоподібних України. Чорноморськ. бот. ж., 8 (4): 459462.

Бойко М.Ф. (2012). Инцертофильность - доминирующий признак мохообразных. Степи Северной Евразии: Под науч. ред. чл.-корр. РАН А.А. Чибилёва. Российская Федерация, Оренбург, 2012. вып IV. C. 123-125.

Бойко М.Ф. (2012). Мохоподібні лівобережжя України: таксономічний аспект. Чорноморськ. бот. ж., 8 (3): 306-312 
Бойко М.Ф. (2012). Рідкісні та зникаючі види мохоподібних адміністративних областей України. Рослинний світ у Червоній книзі України: впровадження глобальної стратегії збереження рослин. Мат. ІІ міжнарод. наук. конф., Умань, 9-12 жовтня 2012 р.: 228-230.

БойкО М.Ф. (2012). Систематика нижчих та вищих несудиннх рослин. Лабораторний практикум. Херсон, 2012. $32 \mathrm{c}$.

БойкО М.Ф. (2013). Ботаніка. Систематика несудинних рослин. Навчальний посібник з грифом МОНУ. Київ, 2013. 276 с.

БойКО М.Ф. (2013). Географічні особливості раритетної фракції бріофлори України. Регіональні проблеми Украӥни: географічний аналіз та пошук шляхів вирішення:11-17.

БойкО М.Ф. (2013). До вивчення бріобіоти агроландшафтів рівнинної частини України. V відкритий з 'їзд фітобіологів Причорномор'я: 3б. тез. доп., Херсон, 25 квітня 2013 р.: 9.

Бойко М.Ф. (2013). Мохоподібні агроценозів рівнинної України. Чорноморськ. бот. ж., 9 (2): $275-282$.

БойКО М.Ф. (2013). Патент на корисну модель № 82865 «Спосіб оцінки ступеня антропогенної дигресії степових екосистем 3 використанням мохоподібних». Розробник патенту Бойко М.Ф. Зареєстровано 27.08.2013 p.

БойКо М.Ф. (2014). Агробріофлора степової зони. VI ботанічні читання пам'яті Й.К.Пачоського: $3 б$. тез між нар. наук. конф., Херсон, 19-22 травня 2014 р.: 24.

Бойко М.Ф. (2014). Індекс пари родин (Pottiaceae/Amblystegiaceae) бріофлор рівнинної України у системі екокоординат «аридність-гумідність». Чорноморськ. бот. ж., 10 (2): 224-233.

Бойко М.Ф. (2014). Матеріали до Червоної книги України (Marchantiophyta). Чорноморськ. бот. ж., 10 (3): 287-304.

Бойко М.Ф. (2014). Особливості онтогенезу мохоподібних степової зони. Онтогенез - стан, проблеми та перспективи вивчення рослин в культурних та природних иенозах: 3б. тез. доп. міжнар. наук. конф., Херсон, 20-22 червня 2014 р.: 10-11.

Бойко М.Ф. (2014). Угруповання Synchitrietum ruraliformis (Bryophyta) Нижньодніпровських пісків. Наука і методика: 12-15.

Бойко М.Ф. (2015). До характеристики «Другого чекліста мохоподібних України». VI відкритий з ’їз фітобіологів Причорномор'я : 3б. тез доп., Херсон-Лазурне, 19 травня 2015 р.: 11-13.

Бойко М.Ф. (2015). Матеріали до Червоної книги України (Sphagnopsida, Bryopsida). Чорноморськ. бот. ж., 11 (4): 449-502.

Бойко М.Ф. (2015). Українські назви мохоподібних. Чорноморськ. бот. ж., 11 (2): 178-216.

БОЙКО М.Ф., ГРУдкОВСьКА I.M. (2012). Рід Tortula у бріофлорі степової зони України. Наука і методика: 4-6.

БойКО М.Ф., ГУРАн С.В. (2011). Мох Ceratodon purpureus у природних фітоценозах степової зони. Наука і методика: 9-13.

БОЙКО М.Ф., ЛОБАЧЕВСЬКА О.В. (2015). Всеволод Максимович Мельничук (до 100-річчя від дня народження). Чорноморськ. бот. ж., 11 (2): 271-272.

БОЙКО М.Ф., МАКОВЕНКО Л.О. (2011). Мох-домінант Syntrichia ruraliformis у псамофітних екосистемах Нижньодніпровських пісків. Наука і методика: 14-16.

БОЙКО М.Ф., СКРЕБОВСьКА С.В., СоБчуК Є.П. (2015). Молекулярно-генетичнгі дослідження мохів Aulacomnioum arenopaludosum Boiko, Physcomitrium arenicola Lazar., Syntrichia ruralis (Hedw.) F.Weber \& Mohr півдня України. VI відкритий з'їд фітобіологів Причорномор'я: Зб. тез доп. Херсон-Лазурне, 19 травня 2015 р.: 13-14.

БойКО М.Ф., МОЙСІєНКО I.I., ХодОсОВЦЕВ О.Є. (2012). Раритетне фіто- та ліхенорізноманіття Національного природного парку «Олешківські піски» (Херсонська область, Україна). Рослинний світ у Червоній книзі України: впровадження глобальної стратегії збереження рослин. Мат. ІІ міжнарод. наук. конф., Умань, 9-12 жовтня 2012 р.: 231-233.

БОЙКО М.Ф., ОРЖАХОВСьКА Д.Г. (2012). Мох Bryum argenteum Hedw. у природних та антропогенних ценозах степової зони. Наука і методика: 6-9.

БОЙКО М.Ф., ДЕРЕВ’ЯНКО В.М., ДЕРЕВ’ЯНКО Н.В., ЗАГОРОДНЮК Н.В., МЕЛЬНИК Р.П., МОЙСІЄНКО І.І., КОРОЛЬОВА О.В., СУШИНСЬКА Н.І., ХОДОСОВЦЕВ О.С. (2011). Чекліст рослин і грибів Ботанічного саду Херсонського державного університету (Відп. ред. М.Ф.Бойко). Херсон, 2011. $108 \mathrm{c}$.

БОЙКО М.Ф., ХОДОСОВЦЕВ О.Є., ПИЛИПЕНКО І.О., МАЛЬЧИКОВА Д.С., МЕЛЬНИК Р.П., ЗАГОРОДНЮК Н.В., ПоНОМАРЬОВА А.А., КЛИМЕНКО В.М. (2013). До вивчення фіто- та ліхенобіоти агроландшафтів півдня України. V відкритий з 'їз фітобіологів Причорномор'я: Зб. тез. доп., Херсон, 25 квітня 2013 p.: 10-11.

ВІрченко В., ОРлОВ О. (2015). Доповнення до бріофлори НПП «Прип'ять-Стохід». Науковий вісник Ужгород. ун-ту. Сер. Біологія, 38-39: 25-30.

ВІРченкО В.М. (2011). Бріологічний гербарій Інституту ботаніки ім. М.Г. Холодного НАН України. Гербарії Украӥни. Index Herbariorum Ucrainicum. Київ, 2011. С. 129-133.

ВІРченко В.М. (2011). Ганна Федорівна Бачурина. 1908-1987. Інститут ботаніки ім. М.Г. Холодного 
НАН України (1921-2011). Віхи історії та сучасність: 410-411.

ВІРченко В.М. (2011). Епіфітні мохи, що збільшують своє поширення в Україні. Ботаніка та мікологія: проблеми і перспективи на 2011-2020 роки: Мат-ли Всеукр. наук. конф., Київ, 6-8 квітня 2011 p.: 171-173.

ВІРЧЕНКО В.М. (2011). Матеріали до бріофлори НПП «Голосіївський». Проблеми відтворення та охорони біорізноманіття Украӥни: Мат-ли Всеукр. наук.-практ. конф., Полтава, 21-22 квітня 2011 р.: $86-88$.

ВІРЧЕНКО В.М. (2011). Матеріали до бріофлори степової зони України. Флорологія та фітосозологія, 2: $300-303$.

ВіРченко B.M. (2012). Dichelyma capillaceum (Dicks.) Myrin (Bryophyta) - кандидат до «Червоної книги України». Рослинний світ у Червоній книзі Украӥни: впровадження Глобальної стратегії збереження рослин : Мат-ли ІІ Міжнар. наук. конф., Умань, 9-12 жовтня 2012 р.: 196-197.

ВІРЧЕНКО В.М. (2012). До бріофлори заказника «Замглай». Біорізноманіття: теорія, практика та методичні аспекти вивчення у загальноосвітній та вищій школі: мат-ли Всеукр. наук.-практ. конф. (присвяч. 100-річчю від дня народж. Д.С. Івашина): 25-27.

ВІРЧЕНКО В.М. (2014). Бріофлора ботанічного заказника «Новий Світ» (АР Крим). Наукові засади природоохоронного менеджменту екосистем Каньйонового Придністров'я: мат-ли Першої міжнар. наук.-практ. конф., присвяченої сторіччю ботан. досліджень у регіоні, м. Заліщики, 11-12 вересня 2014 р.: 70-73.

ВІРЧЕнКО В.М. (2014). Мохоподібні природно-заповідних територій Українського Полісся. Київ, 2014. $224 \mathrm{c}$.

ВІРЧЕнко В.М. (2015). Бріологічні дослідження А.Й. Рошаль у Кримському заповіднику. Внесок натуралістів-аматорів у вивчення біологічного різноманіття: Мат-ли Міжнар. наук. конф., присвяч. 200-річчю від дня народж. Л.Вагнера, Берегово, 14-16 травня 2015 р.: 178-183.

ВІРЧЕнКО В.М. (2015). Збірка мохоподібних Д.К. Зерова і Л.Я. Партики з околиць м. Кам'янки Черкаської області. VI відкритий з’їд фітобіологів Причорномор'я: 3б. тез доп., ХерсонЛазурне, 19 травня 2015 р.: 16.

ВІРченКО В.М., ГОДиНА О.О. (2013). Доти НПП «Голосіївський» (м. Київ) як оселище для мохів. Рослини та урбанізація: Мат-ли третьої міжнар. наук.-практ. конф., Дніпропетровськ, 19-20 березня 2013 p.: 23-25.

ВІРЧЕНКО В.М., МАЛА Ю.І. (2014). Нові та рідкісні мохоподібні для Криму. VI Ботанічні читання пам'яті Й.К. Пачоського: Збірка тез доп. міжнар. наук. конф., Херсон, 19-22 травня 2014 р.: 25-26.

ВІРченко В.М., НиПОРко С.О. (2011). Мохоподібні НПП «Гуцульщина». Національний природний парк “Гуиульщина" - Природно-заповідні території України: 152-169.

ВІРченко В.М., НиПорко С.О. (2013). Мохоподібні. Список мохоподібних НПП «Гуцульщина». Національний природний парк “Гуцульщина”. Від. ред. В.В. Пророчук та ін. Львів: 128-129, 337-340.

ВІРченко В.М., Орлов О.О. (2011). Нові та рідкісні мохоподібні для Житомирської області. Вісник Житомир. націонал. агроеколог. ун-ту, 1 (28): 314-322.

ВІРченко В.М., ПРяДКО О.І. (2013). Осередок сфагнових мохів у м. Києві (НПП «Голосіївський»). Екологія водно-болотних угідь і торфовищ: Мат-ли Міжнар. наук.-практ. конф. «Методи $i$ технології стратегічного планування розвитку територій. Розвиток системи управління водно-болотних угідь міжнародного значення в Україні», Київ, 1 лютого 2013 р.: 28-30.

ВІРЧЕНКО В.М., ПРЯДКО О.І. (2014). Особливості бріофлори Національного природного парку «Голосіївський» (м. Київ). Регіональні аспекти флористичних і фауністичних досліджень: мат-ли Першої міжнар. наук.-практ. конф., м. Хотин, 10-12 квітня 2014 р.: 32-35.

ВІРченко В.М., ШеВеРА М.В. (2013). Колекція мохоподібних В.В. Монтрезора в Гербарії Інституту ботаніки імені М.Г. Холодного НАН України. Укр. бот. журн., 70 (6): 800-804.

ВІРченко В.М., Шиян Н.М. (2014). Мохоподібні з колекції Ж.Е. Жілібера в Гербарії Інституту ботаніки імені М.Г. Холодного НАН України (KW). Укр. бот. журн., 71 (3): 376-380.

ВІРченко В.М., ОРЛОВ О.О., ГолОВко О.В. (2014). Мохоподібні Рівненського природного заповідника. Екологія водно-болотних угідь і торфовищ: Мат-ли ІІІ Міжнар. наук.-практ. круглого столу, Київ, 3 лютого 2014 р.: 59-63.

ВІРЧЕНКО В.М., ПАРТИКА Л.Я., ОРЛОВ О.О. (2012). Рідкісні мохоподібні Поліського природного заповідника (Житомирська область). Вісник Житомир. націонал. агроеколог. ун-ту, 2 (31): 204-212.

ГАПон С.В. (2011). Мохова рослинність урочища «Яри-Поруби» (Пирятинський р-н, Полтавська обл.). Пирятинські екологічні читання: м-ли Всеукр. наук.-практ. конф. Полтава: 49-51.

ГАПон С.В. (2011). Мохоподібні Лісостепу України (рослинність та флора) автореф. дис. ... д-ра біол. наук : спец. 03.00.05 «Ботаніка». Київ, 2011. 36 с.

ГАПОН С.В. (2011). Напрямки антропогенної трансформації бріофлори Лісостепу України. Проблеми 
відтворення та охорони біорізноманіття Украӥни: м-ли Всеукр. наук.-практ. конф., Полтава, 21-22 квітня 2011 р.: 74-76.

ГАПОН С.В. (2011). Особливості мохового покриву та бріофлори Лісостепу України. Ботаніка та мікологія: проблеми та перспективи на 2011 - 2020 роки : м-ли Всеукр. наук. конф. Київ, 6-8 квітня 2011 р.: 8-9.

ГАПОН С.В. (2012). Бріофлора і мохова рослинність національних природних парків Лісостепу України. Чорноморськ. бот. ж., 8 (2): 214-222.

ГАПОН С.В. (2012). Еколого-ценотичні особливості мохоподібних епілітних бріоценозів Лісостепу України. Біорізноманіття теорія, практика та методичні аспекти вивчення загальноосвітній школі: м-ли Всеукр. наук.-практ. конф. Полтава: 29-32.

ГАПон С.В. (2012). Мохоподібні як об’єкт вивчення науково-дослідницьких робіт учнів, студентів, магістрантів. Проблеми відтворення та охорони біорізноманіття: м-ли Всеукр наук.-практ. конф., Полтава, 19-20 квітня 2012 р.: 44-46.

ГАПОН С.В. (2012). Синантропізація бріофлори та мохової рослинності Лісостепу України. Навколишне середовище $і$ здоров'я людини: м-ли V Всеукр. наук.-практ. семінару, Полтава, 23 вересня 2011 p.: 21-23.

ГАПОН С.В. (2012). Стан та перспективи вивчення мохоподібних НПП «Кременецькі гори». Природозаповідання як основна форма збереження біорізноманіття: Мат-ли Всеукр. наук.практ. конф., 20-21 вересня 2012 р. Кременеиь: 24-26.

ГАПОН С.В. (2012). Участь видів родини Plagiomniaceae в утворенні мохового покриву Лісостепу України. Чорноморськ. бот. ж., 8 (3): 256-267.

ГАПОН С.В. (2013). Антропогенна трансформація бріофлори та мохового покриву Лісостепу України. Вісник Львівського ун-ту. Серія Біологічна, 62: 82-90.

ГАПОН С.В. (2013). Бріоугруповання - як об'єкти вивчення науково-дослідницьких робіт учнів, студентів та магістрантів. Методика навчання природничих дисциилін у вищій та середній школі: Матли Міжнар. наук.-практ. конф., Полтава, 29-30 травня 2013 р.: 68-70.

ГАПон С.В. (2013). Бріоугруповання природних типів рослинності Лісостепу України Чорноморськ. бот. ж., 9 (1): 258-267.

ГАПОН С.В. (2013). Географічна структура бріофлори Лісостепу України. Науковий вісник Ужсгородського ун-ту, серія Біологія, 32: 60-64.

ГАПОН С.В. (2013). Методичний аспект дослідження мохової рослинності. Укр. бот. журн., 70 (3): $392-$ 397.

ГАПОН С.В. (2013). Місцеві мохоподібні як об'єкт вивчення бріорізноманіття шкільного курсу біології. Імідж сучасного педагога, 3: 65-67.

ГАПон С.В. (2013). Огляд схем класифікації мохової рослинності Західної та Центральної Європи. Чорноморськ. бот. ж., 9 (2): 258-267.

ГАПОН С.В. (2013). Рідкісні та зникаючі види мохоподібних Лісостепу України. Наук. записки Тернопільського наи. пед. ун-ту ім. Володимира Гнатюка. Серія: Біологія, 3 (56): 5-10.

Гапон С.В. (2014). Бріоугруповання лісосмуг Лісостепу України. Наук. вісник Ужгородського ун-ту, серія Біологія, 34: 60-63.

ГАПОН С.В. (2014). Каріологічні дослідження мохоподібних Лісостепу України. Теоретичні та прикладні аспекти розвитку природничих дисциилін: Мат-ли Міжнародної наук.-практ. конф., Полтава, 20-21 листопада 2014 р.: 58-61.

ГАПОН С.В. (2014). Мохова рослинність РЛП «Диканський». Теоретичні та прикладні аспекти розвитку природничих дисциплін: м-ли Міжнародної наук.-практ. конф. Полтава, 20-21 листопада 2014 p.: 58-61.

ГАПон С.В. (2014). Синтаксономія мохової рослинності України (Лісостеп). Монографія. Полтава, 2014. $88 \mathrm{c}$.

ГАПОН С.В. (2014). Сучасний стан та перспективи дослідження мохоподібних РЛП «Диканський». Регіональний ландшафтний парк - центр збереження біорізноманіття та екологічного просвітництва: зб. статей наук.-практ. конф., присвяченої 20-річчю парку, смт. Диканька, 22 жовтня 2014 р.: 43-46.

ГАПон С.В. (2015). Мохоподібні заповідників Лісостепу України. Біологія та екологія: 8-14.

ГАПон С.В. (2015). Патріарх ботанічної науки: до 120-річчя від народження академіка Д.К. Зерова. Біологія та екологія: 106-108.

ГАПОН С.В. (2015). Созологічний напрямок досліджень мохоподібних Лісостепу України. Проблеми відтворення та охорони біорізноманіття Украӥни: Мат-ли Всеукр. наук. практ. конф. Полтава: 27-29.

ГАПОН С.В. (2015). Участь печіночників в утворенні бріоценозів мохової рослинності Лісостепу України. Чорноморськ. бот. ж., 11 (1): 73-83. 
ГАПОН С.В. (2015). Эколого-ценотический аспект исследования мохообразных Лесостепи Украины. Актуальные проблемь биологии и методики ее преподавания в школе и вузе: Мат-ль III Междунар. заоч. науч.-практ. конф., Омск, 30 апреля - 5 мая 2015 г.: 14-16.

ГАПОН С.В., ГРИНЬОВА К.І. (2013). Особливості проведення бріологічної екскурсії в природу на прикладі РЛП «Диканський». Біорізноманіття Украӥни в світлі ноосферної концепції академіка B.I. Вернадського: Мат-ли Всеукр. науково-практ. конф., Полтава, 18-19 квітня 2013 р.: 178-180.

ГАПОН С.В., ГРИшАЙ Д. (2015). Мохоподібні Андріяшівсько-Гудимівського заказника (Сумська обл.). Проблеми відтворення та охорони біорізноманіття України: Мат-ли Всеукр. наук. практ. конф.: 31-33.

ГАПОН С.В., МАСТЮХ К.В. (2014). Мохоподібні пам’ятки природи «Бутова гора» (Полтавська обл.) та їх участь в утворенні бріоугруповань. Біорізноманіття України в світлі ноосферної концепиії академіка В. І. Вернадського: Мат-ли Всеукр. наук.-практ. конф. Полтава: 58-60.

ГАПОН С.В., МАСТЮХ К.В. (2014). Особливості формування ботанічних та біоекологічних понять при вивченні мохоподібних. Методика навчання природничих дисичилін у середній та вищій иколі» (ХХІ Каришинські читання): Мат-ли Міжнарод. наук.-практ. конф., Полтава, 29-30 травня 2014 р.: 52-54.

ГАПОН С.В., МАСТЮХ К.В. (2014). Синузіальний підхід до вивчення мохової рослинності України. Природничі дослідження на Поділлі: 3б. тез Міжнар. наук.-практ. конф., присвяченої 10річчю природничого факультету Кам'янецьь-Подільського нац. ун-ту ім. Івана Огієнка, Кам'янець-Подільський, 23-25 вересня 2014 р. Кам'янець-Подільський: 27-29.

ГАПОН С.В., ПотРАВНА Т.О. (2014). Родина мнієві в флорі Полтавщини та ії участь в утворенні бріоугруповань. Актуальні питання природничих досліджень: Мат-ли студентської наук.практ. конф. Полтава: 3-6.

ГАПОН С.В., ГАПОН В.В., ГАПОН Ю.В. (2012). Місце міських мохоподібних при проведенні екскурсій $з$ ботаніки. Організаційно-методичні основи екскурсійної роботи вчителя природничих дисциплін: Мат-ли Всеукраїн. наук.-практ. конф. Полтава: 69-72.

ГАПОН С.В., ГАПОН Ю.В., ГРИНЬОВА К.І. (2010). Роль міських парків як об’єктів рекреації в збереженні бріорізноманіття. Навколишне середовище $і$ здоров'я людини: м-ли IV Всеукр. наук.-практ. семінару, Полтава, 23 вересня 2010 р.: 35-38.

ГАПОН С.В., ГАПОН Ю.В., МАСТЮХ К.В. (2015). Стан та напрямки досліджень мохової рослинності України. Актуальні проблеми ботаніки та екології: Мат-ли Міжнар. конф. молодих учених, присвяченої 120-річчю від дня народження Д.К. Зерова, Полтава, 15-20 вересня 2015 р.: 22.

ГАПОН С.В., ГАПОН Ю.В., МАСТЮХ К.В. (2015). Становлення бріологічного гербарію Полтавського національного педагогічного університету. Проблеми відтворення та охорони біорізноманіття Украӥни: Мат-ли Всеукр. наук. практ. конф.: 29-31.

ГАПОН Ю.В. (2015). Мохоподібні та мохова рослинність лісових масивів НПП «Нижньосульський» (Полтавська область). Вісник проблем біології і медицини, 4 (2): 71-74.

ГАПОН Ю.В. (2015). Эпигейные мохообразные городских экосистем Полтавщины. Актуальные проблемы биологии и методики ее преподавания в школе и вузе: Мат-ль ІІІ Междунар. Заоч. Науч.практ. конф., Омск, 30 апреля - 5 мая 2015 г.: 16-19.

ГАПОНЕНКО М.Б., ЛЕБЕДА А.П., АЛЬОХІН О.О., БАГЛАЙ К.М., БЕРЕЗКІНА В.І., БІЛИК О.М., БОЙКО М.Ф. (2011). Каталог раритетних рослин ботанічних садів і дендропарків України. Київ, 2011. 183 с.

ДАнилКІв І.С., КОстюК А.С. (2011). Нові місцезнаходження Sphagnum riparium Ångstr. в Українських Карпатах. ХІІІ з ’̈зз Укр. ботан. тов-ва: мат-ли з '̈зду, Львів, 19-23 вересня 2011 р.: 275.

ДАНИЛКІВ І.С., ЛОБАЧЕВСьКА О.В., РАБИК І.В., ШОВГАН Ю.А. (2015). Мохоподібні (Bryobionta) національного природного парку “Північне Поділля". Природа Волині $і$ Поділля:дослідження та охорона: мат-ли Першої міжнар. науко.-практ. конф., Броди, 3-5 червня 2015 р.: 32-35.

ДАнИЛКІв І.С., РАБИк І.В. (2014). Рідкісні мохи (Bryophyta) природного заповідника «Медобори». Праці Наукового товариства ім. Шевченка. Екологічний збірник, 39: 207-213.

ДАНИЛКІВ І.С., РАБИК І.В., ЩЕРБАЧЕНКО О.І., КІт Н.А. (2011). Особливості формування бріофітного покриву на відвалах сірчаного видобутку. ХІІІ з ’їзд Укр. Ботан. тов-ва: мат-ли з '̈ззу, Львів, 19-23 вересня 2011 р.: 276.

ДЕМЕНТЬЕВА А.Н., МАШТАЛЕР А.В. (2013). Бриологические исследования на территории г. Бердянска Запорожской области. Биоразнообразие. Экология. Адаптащия. Эволющия: Maт-ль VI Междунар. конф. молодых ученых, Одесса, 13-17 мая 2013 г.: 18-19.

ДЕМЕНТЬЕВА А.Н., МАШТАЛЕР А.В. (2013). Изменение морфометрических показателей листа трансплантатов Orthotrichum pallens Bruch ex Brid. как индикатор загрязнения окружающей среды. Охрана окружающей среды и рациональное использование природных ресурсов: МатХХІІІ Всеукр. научн. конф. аспирантов и студ., Донеик, 16-16 апреля 2013 г.: 42-43.

ДЕМЕНТЬєВА Г.М., МАШТАЛЕР О.В., КАЧУР Л.Ю. (2014). Трансплантати моху Orthotrichum pallens Bruch ex Brid. як біотестери забруднення атмосферного повітря. Молодь i поступ біологї: Мат-ли X Міжнар. наук. конф. студентів і аспірантів, Львів, 8-11 квітня 2014 р.: 106-107. 
ДЕМКІВ О.Т., КАГАЛО О.О., ЛОБАЧЕВСЬКА О.В., МАРИСКЕВИЧ О.Г., ЦАРИК Й.В., БАЇК О.Л., БЕДНАРСЬКА І.О., БІЛОНОГА В.М., ГНАТІВ П.С., ДАНИЛКІВ І.С., ДМИТРАХ Р.І., ЖИЛЯЄВ Г.Г., КИЯК В.Г., КИЯК Н.Я., КОБІВ Ю.Й., КОЗЛОВСЬКИЙ В.І., КОРОТЧЕНКО В.В., НЕСТЕРУК Ю.Й., РЕШЕТИЛО О.С., СКІБІЦКА Н.В., ТКАЧИК В.П., ХОРКАВЦІВ Я.Д. (2011). Роль природних екотипів рослин у формуванні біорізноманіття та стійкості фітосистем до несприятливих умов. Львів, 2011. 180 с.

ЗАГОРОДНЮК Н.В. (2011). Гігрофітний екоелемент в бріофлорі рівнинно-степового Криму. Наука $i$ методика: 18-22.

ЗАГОРОДНЮК Н.В. (2011). Мохообразные парков г. Керчь (АР Крым, Украина). Актуальні проблеми ботаніки та екології: Мат-ли міжнар.конф. молодих учених, Рівненська обл., м. Березне, 9-13 серпня 2011 р.: 26-27.

ЗАГОРОднЮК Н.В. (2011). Раритетні мохоподібні рівнинної частини Криму. Мат-ли ХII з'їзу Укр. ботан. тов-ва, Львів, 19-23 вересня 2011 р.: 284.

ЗАГОРОДНЮК Н.В. (2012). Мохообразные в экосистемах Караньского плато (АР Крым, Украина). Биоразнообразие и устойчивое развитие: Мат-ль II Междунар. науч.-практ. конф., Симферополь, 12-16 сентября 2012 г.: 66.

ЗАГОРОДНЮК Н.В. (2013). Мохоподібні в екосистемах пустельних полиново-злакових степів рівнинностепового Криму. V відкритий з '̈зд фітобіологів Причорномор'я: Зб.тез доповідей, Херсон, 25 квітня 2013 р.: 16.

ЗАГОРОднЮК Н.В. (2014). Бріоіндикація чистоти повітря як складова фонового моніторингу в об’ єктах природно-заповідного фонду. Фундаментальні та прикладні дослідження в біологї: Мат-ли III Міжнар.наук.конф.студентів, аспірантів, молодих вчених, Донецьк, 24-27 лютого 2014 р.: $152-153$.

Загороднюк Н.В. (2014). Мохообразные в экотопах петрофитных степей равнинно-степного Крыма. Биоразнообразие и устойчивое развитие: Мат-льл докл. ІІІ Междунар. науч.-прак. конф., Симферополь, 15-19 сентября 2014 г.: 130-131.

ЗАГОРОднЮк Н.В. (2014). Мохоподібні лісосмуг як компонент бріобіоти агроландшафтів півдня України. VI Ботанічні читання пам'яті Й.К. Пачоського: 3б. тез доповідей міжнар.наук.конф., Херсон, 19-22 травня 2014 р.: 28-30.

ЗАГОРОднЮК Н.В. (2015). Лісові масиви півдня України як оселища мохоподібних. VI відкритий з’їд фітобіологів Причорноморя: 3б. тез. доп., Херсон, 19 травня 2015 р.: 25-26.

ЗАГОРОДНЮК Н.В., БЕРЕЗОВСЬКА Д. (2015). Бріофіти в екотопах урбанізованого середовища. Біологічні дослідження - 2015: 3б. наук. праць.: 263-265.

ЗАГОРОДНЮК Н.В., БойКО М.Ф. (2011). Бриоразнообразие ландшафтного заказника «Джангульский» (АР Крым). Заповедники Крыма. Биоразнообразие и охрана природы в Азово-Черноморском регионе: Мат-ль VI Междунар. науч.-практ. Конф., Симферополь, 20-22 октября 2011 г.: 172-177.

ЗАГОРОДНЮК Н.В., БОЙКО М.Ф. (2012). Раритетний компонент бріофлор степових заповідників Кримського півострова. IV-ий відкритий з'їз фітобіологів Причорномор'я, присвячений ювілею проф. М.Ф. Бойка: Зб. тез доповідей, Херсон, 19 січня 2012 р.: 89.

ЗАГОРОДНЮК Н.В., ДРАГАНЮК А. (2013). Родина Amblystegiaceae в бріофлори Херсонської області. Наука і методика: 13-15.

ЗАГОРОднЮк Н.В., Лось С. (2012). До характеристики кальцефільних мохоподібних півдня України. Наука і методика: 11-13

ЗАГОРОДНЮК Н.В., ПОГАРСЬКА М.Р. (2016). Життєві стратегї̈ мохоподібних в межах урбанізованого середовища (на прикладі бріофлори міста Херсон). Рослини та урбанізація: Мат-ли V-ï Міжнар. наук.-практ. конф., Дніпропетровськ, 16-17 лютого 2016 р.: 69-71.

ЗАГОРОДНЮК Н.В., ПОГАРСЬКА М.Р. (2016). Рідкісні мохоподібні в бріофлорі міста Херсон (Україна): епігейна фракція. Актуальні питання розвитку біологї та екологї: Мат-ли міжнар. наук.практ. конф., Вінниия, 3-7 жовтня 2016 р.: 316-318.

ЗАГОРОДНЮК Н.В., СєДІнІнА С. (2014). Мохоподібні Дніпровського району міста Херсона. Наука $i$ методика: 25-28.

ЗИНЧЕНКО Ю.В., МАШТАЛЕР А.В. (2013). Биоморфологическая структура мохообразных антропогенно нарушенных территорий г. Снежное Донецкой области. Біорізноманіття. Екологія. Адаптація. Еволючія: Мат-ли VI Міжнар. конф. молодих вчених: 24-25.

ЗИНЧЕНКО Ю.В., МАШТАЛЕР А.В., ВЕЛИГОДСКАЯ А.К. (2014). Биомониторинг загрязнения атмосферного воздуха с применением трансплантатов мха Amblystegium subtile (Hedw.) Schimp. Охорона навколишнього середовища та раціональне використання природних ресусів: 3б. доп. XXIV Всеукр. наук. конф. аспірантів і студентів: 10-13.

ЗІНЧЕНКО Ю.В., МАШТАЛЕР О.В., САФОНОВ А.І., ФЕДОТОВ О.В., ВЕЛИГОДСЬКА А.К. (2014). СПосіб індикації забруднення атмосферного повітря за допомогою визначення кількісного вмісту поліфенолів у гаметофітах мохоподібних. Пат. 92028 України, МПК A99Z 99/00. заявник та 
власник патенту Донецький національний університет. - № u201402042; заявка 28.02.2014; опубл. 25.07.2014, Бюл. № 14.

КАРПІНЕЦЬ Л.І., БАРАНОВ В.І. (2013). ВПлив водних екстрактів прижиттєвих виділень мохів 3 породних відвалів вугільних шахт на ризогенез живців квасолі. Молодь $і$ постуn біологіï: зб. тез IX Міжнар. наук. конф. студентів та аспірантів, Львів, 16-19 квітня 2013 р.: 205-206.

КАРПІНЕЦЬ Л., ЛОБАЧЕВСЬКА О., БАРАНОВ В. (2014). ВПЛИв бріофітів на вміст макроелементів та органічного вуглецю в техноземах відвалів Червоноградського гірничопромислового комплексу. Вісник Харківського начіонального аграрного ун-ту. Серія Біологія, 3 (33): 52-59.

КАРПІНЕЦЬ Л., ЛОБАЧЕВСЬКА О., БАРАНОВ В. (2014). ВПЛИв бріофітного ПоКрИвУ на уМови едафотоПу породних відвалів Червоноградського гірничопромислового комплексу. Вісник Львівського унту. Серія біол., 65: 255-265.

КАРПІНЕЦЬ Л., ЛОБАЧЕВСЬКА О., БАРАНОВ В. (2015). ВПЛИв стресових чинників породних відвалів вугільних шахт на вміст фенольних сполук у гаметофіті мохів. Молодь і постуn біологіï: матли ХІ Міжнар. конф. студентів і аспірантів, Львів, 20-23 квітня 2015 р.: 515-516.

КАРПІНЕЦЬ Л.І., ЛОБАЧЕВСЬКА О.В., БАРАНОВ В.І. (2013). Зміни мікрокЛіматичних умов субстратів породних відвалів вугільних шахт за впливу бріофітного покриву. Стан і біорізноманіття екосистем Шацького національного природного парку: мат-ли наук. конф., Шацьк, 12-15 вересня 2013 р.: 33-34.

КАРПІНЕЦЬ Л.І., ЛОБАЧЕВСЬКА О.В., БАРАНОВ В.І. (2014). ВПЛИВ бріофітНоГО ПоКрИвУ на вміст біогенНИх елементів у техноземах породних відвалів. Стан і біорізноманіття екосистем Шацького начіонального природного парку: мат-ли наук. конф., Шаџьк, 11-14 вересня 2014 р.: 31-32.

КАРПІНЕЦЬ Л.І., ЛОБАЧЕВСЬКА О.І., БАРАНОВ В.І. (2015). Вміст Пігментів фотосинтезУ та проліну у гаметофіті мохів на породних відвалах вугільних шахт. Стан $і$ біорізноманіття екосистем Шацького нащіонального природного парку: мат-ли наук. конф., Шащьк, 10-13 вересня 2015 р.: 39.

Кит Н.А. (2012). Устойчивость мхов к водному дефициту на девастированных территориях выработки серы. Биологические системы: устойчивость, принципы и механизмы функиионирования: мат-лы IV Всероссийской науч.-практич. конф., Российская Федерачия, Нижний Тагил, 26-29 марта 2012 2.: 42-43.

Кит Н.А. (2015). Особенности толерантности вегетативных и генеративных клонов мха Bryum argenteum Hedw. к водному дефициту. Бриология: традиции и современность: Сборник статей по материалам Междунар. бриолог. конф., посвященной 100-летию со дня рождения А.Л. Абрамовой, Санкт-Петербург, 12 - 16 октября 2015 г.: 60-63.

Кияк Н.Я. (2011). Вплив свинцю на показники окислювального стресу в пагонах моху Fontinalis antipyretica Hedw.. Відновлення порушених природних екосистем: мат-ли IV міжнар. наук. конф., Донецьк, 18-21 жовтня 2011 р.: 170-172.

Кияк Н.Я. (2012). Вплив іонів свинцю на ріст і окислювальний стрес гаметофіту Funaria hygrometrica Hedw. на різних стадіях розвитку. Чорноморськ. бот. ж., 8 (2): 171-177.

Кияк Н.Я. (2012). Морфо-фізіологічна адаптація моху Bryum argenteum Hedw. до нафтового забруднення середовища. $I V$ відкритий з'їзд фітобіологів Причорномор'я, присвячений ювілею професора Михайла Федосійовича Бойка: Зб. тез доп., Херсон, 19 січня 2012 p.: 89.

Кияк Н.Я. (2012). Функціональна роль бріофітів у відновленні техноземів сірчаного видобутку. Рекультиваиія складних техноекосистем у новому тисячолітті: ноосферний аспект: Мат-ли міжнар. наук.-прак. конф., Дніпропетровськ, 29-30 травня 2012 р.: 305-306.

Кияк Н.Я. (2013). Особенности адаптации мха Bryum argenteum Hedw. к нефтяному загрязнению. Инновационные направления современной физиологии растений: мат-лы Всероссийской науч. конф. с междунар. участием, Москва, 2-6 июня 2013 г.: 285.

Кияк Н.Я. (2013). Особливості адаптації моху Bryum argenteum Hedw. до нафтового забруднення. Вісник Львівського ун-ту. Серія біологічна, 63: 285-294.

Кияк Н.Я. (2013). Оцінка фізіологічних показників водного режиму моху Bryum argenteum Hedw. в умовах нафтового забруднення. Рослини та урбанізація: мат-ли III Міжнар. наук.-практ. конф., Дніпропетровськ, 19-20 березня 2013 р.: 126-128.

Кияк Н.Я. (2013). Стан прооксидантно-антиоксидантної системи моху Bryum argenteum Hedw. в умовах нафтового забруднення. V відкритий з'їз фітобіологів Причорномор'я: зб. тез доп., Херсон, 25 квітня 2013 р.: 17.

Кияк Н.Я. (2013). Фотосинтетична активність мохів на девастованих територіях видобутку сірки. Вісник Львівського ун-ту. Серія біологічна, 62: 170-179.

Кияк Н.Я. (2014). Адаптація піонерних видів мохів до екологічних умов на території відвалу видобутку сірки. Перспективы интродукции декоративных растений в ботанических садах и дендропарках: мат-ль Междунар. науч. конф., Симферополь, 23-26 сентября 2014 г.: 168171. 
Кияк Н.Я. (2014). Особливості фотосинтетичної активності мохів на девастованих територіях видобутку сірки. Інтродукція, збереження та моніторинг рослинного різноманіття: матеріали Міжнар. наук. конф., присвяченій 175-річчю Ботанічного саду імені акад. О.В. Фоміна Київського національного університету ім. Тараса Шевченка, Київ, 20-24 травня 2014 р.: 189-190.

Кияк Н.Я. (2014). Роль мохів у відновленні техногенного субстрату на відвалі сірчаного видобутку. Наук. вісник Ужгородського національного ун-ту: Біологія, 37: 68-78.

Кияк Н.Я. (2014). Роль осмотично активних речовин в адаптації мохів до несприятливих мікрокліматичних умов на території відвалу видобутку сірки. Відновлення порушених природних екосистем: мат-ли IV міжнар. наук. конф., Донецьк, 12-15 травня 2014 р.: 380.

Кияк Н.Я. (2014). Сезонні зміни вмісту компонентів глутатіоно-аскорбатного циклу у мохах на території відвалу видобутку сірки. Вісник Львів. ун-ту. Серія біологічна, 67: 309-320.

Кияк Н.Я. (2015). Адаптация мхов к водному дефициту. Бриология: традиции и современность: Сб. статей по мат-лам Междунар. бриолог. конф., посвященной 100-летию со дня рождения А. Л. Абрамовой, Санкт-Петербург, 12 - 16 октября 2015 г.: 63 -67.

Кияк Н.Я. (2015). Особливості водного режиму у бріофітів із різною чутливістю до дефіциту вологи. VI відкритий з їзд фітобіологів Причорномор'я: мат-ли наук. конф., Херсон, 19 травня 2015 р.: $25-27$.

Кияк Н.Я. (2015). Особливості фізіологічних показників водного режиму у бріофітів із різною толерантністю до дефіциту вологи. Вісник Львівського ун-ту. Серія Біологія, 70: 214-223.

Кияк Н.Я., БАїк О.Л. (2011). Еколого-фізіологічна характеристика домінуючих видів мохів на територіях сірчаного виробництва. Наукові записки Тернопільського держ. пед. ун-ту ім. Володимира Гнатюка. Серія: Біологія, 2 (47): 102-106.

КИяк Н.Я., БАїк О.Л. (2011). Участь бріофітів у відновленні девастованих територій сірчаного видобутку. Біологічні Студї, 6 (2): 22-36.

КияК Н.Я., БАїк О.Л. (2012). Роль бріофітного покриву у ренатуралізації техногенних субстратів на території видобутку сірки. Вісник Львівського ун-ту. Серія біологічна, 59: 114-121.

Кияк Н.Я., БУньо Л.В. (2012). Механізми пристосування моху Bryum argenteum Hеdw. до нафтового забруднення. Біологічні Студіï, 6 (3): 165-176.

КИяк Н.Я., ХОРКАВЦІВ Я.Д. (2015). Адаптація бріофітів до водного дефіциту на території відвалу видобутку сірки. Укр. ботан. журн., 72 (6): 645-651.

КІт Н.А. (2011). Стійкість моху Bryum caespiticium (Hedw.) до водного дефіциту. Відновлення порушених природних екосистем: мат-ли IV міжнар. наук. конф., Донеиьк, 18-21 жовтня 2011 р.: 163165.

КІт Н.А. (2012). Особливості стійкості мохів до водного дефіциту на девастованих територіях видобутку сірки. Наукові основи збереження біотичної різноманітності, 3 (10): 191-198.

КІт Н.А. (2012). Особливості структури дернин мохів на девастованих територіях сірчаного видобутку. Рекультивація складних техноекосистем у новому тисячолітті: ноосферний аспект: мат-ли міжнар. наук.-практич. конф., Дніпропетровськ, 29-30 травня 2012 р.: 306-307.

Кіт H.A. (2013). Адаптація моху Barbula unguiculata Hedw. до водного дефіциту на посттехногенних територіях сірчаного видобутку. Рослини та урбанізація: мат-ли III Міжнар. наук.-практич. конф., Дніпропетровськ, 19-20 березня 2013 р.: 100-101.

КІт Н.А. (2013). Вплив водного дефіциту на активність антиоксидантних ферментів в пагонах моху Barbula unguiculata Hedw. V відкритий з 'їз фітобіологів Причорномор'я: зб. тез доп., Херсон, 25 квітня 2013 р.: 18.

Кіт Н.А. (2014). Адаптація Bryum caespiticium і Barbula unguiculata до водного дефіциту на девастованих територіях видобутку сірки. Інтродукція, збереження та моніторинг рослинного різноманіття: мат-ли Міжнар. наук. конф., присвяченій 175-річчю Ботанічного саду імені акад. О.В. Фоміна Київського національного університету імені Тараса Шевченка, Київ, 20-24 травня 2014 р.: 184-185.

КІт Н.А. (2014). Толерантність вегетативних і генеративних клонів Bryum argenteum до водного дефіциту. Відновлення порушених природних екосистем: мат-ли V Міжнар. наук. конф., Донецьк, 12-15 травня 2014 р.: 381.

КІт Н.А. (2015). Дослідження морфологічної структури і тривалості стадій онтогенезу мохів 3 різною життєвою стратегією на девастованих територіях видобутку сірки. VI відкритий з’ізд фітобіологів Причорномор'я: матеріали наук. конф., Херсон, 19 травня 2015 р.: 28-30.

КОЛОС О.А., МАШТАЛЕР А.В. (2013). Индикация загрязнения окружающей среды с использованием листовых пластинок трансплантатов мха Ceratodon purpureus (Hedw.) Brid. Охорона навколишнього середовища та раціональне використання природних ресурсів: зб. доп. ХХІІІ Всеукраӥнської наук. конф. аспірантів і студентів. Донецьк: 46-47

КОЛОС О.А., МАшТАЛЕР А.В. (2013). Экологическая характеристика мохообразных г. Доброполье (Донецкая обл.). Биоразнообразие. Экология. Адаптаџия. Эволюичя: мат-ль VI Междунар. конф. молодых ученых, Одесса, 13-17 мая 2013 г.: 31-32. 
КОмІСАР О., БОйКО М.Ф. (2013). Важкі метали в гаметофітах моху Bryum argenteum Hedw. та грунтах на територіях заводів міста Миколаєва (Україна). Чорноморськ. бот. жс., 9 (4): 533-541.

КОМІСАР О.С., ЗАГОРОДНЮК Н.В. (2012). Мохоподібні околиць промислових підприємств міста Миколаєва (Україна). Чорноморськ. бот. ж., 8 (1): 87-97.

КОНДРАТЮК С.Я., МАмчУР 3.І., ХмІЛЬ Т.С. (2011). Колекція мохоподібних А. Ремана з Південної Африки.

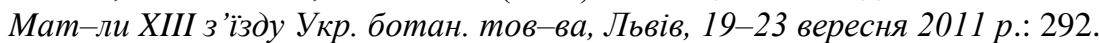

КОНДРАТЮК С.А., ВІРЧЕНКО В.М., ЛОБАЧЕВСЬКА О.В. (2011). Ліхенологія та бріологія: Інститут ботаніки ім. М.Г. Холодного НАН України (1921-2011). Віхи історії та сучасність. Київ, 2011. C. $138-164$.

КОНШУК В.В., МОСЯКІН С.Л., ЦАРЕНКО П.М., КОНДРАТЮК С.Я., БОРИСОВА О.В., ВІРЧЕНКО В.М., ПРИДЮК М.П., ФІцАЙЛО Т.В., ГАВРИСь Г.Г., ТИТАР В.М., ШУПОВА Т.В. (2012). Червона книга Київської області. Агроекологічний журнал, 3: 46-58.

КОНЩУК В.В., МОСЯКІН С.Л., ЦАРЕНКО П.М., КОНДРАТЮК С.Я., БОРИСОВА О.В., ВІРЧЕНКО В.М., ПРИДЮК М.П., ФІЦАЙЛО Т.В., ГАВРИСЬ Г.Г., ТИТАР В.М., ШУПОВА Т.В. (2012). Методика створення списку регіонально рідкісних видів мікобіоти, флори, фауни (на прикладі Київської області). Київ, 2012. 38 с.

ЛОБАЧЕВСьКА О.В. (2011). Андрій Созонтович Лазаренко 1901-1979. Інститут ботаніки ім. М.Г. Холодного НАН Украӥни (1921-2011). Віхи історії та сучасність: 399-402.

ЛоБАЧЕВСЬКА О.В. (2011). Екологічні особливості та репродуктивна стратегія мохоподібних на антропогенно трансформованих територіях. Наукові записки Тернопільського держ. педагог. ун-ту ім. Володимира Гнатюка. Серія: Біологія, 2 (47): 109-113.

ЛоБАЧЕВСЬКА О.В. (2011). Морфо-фізіологічні особливості стійкості мохів до техногенного забруднення. Мат-ли ХІІІ з '̈ззу Укр. ботан. тов-ва., Львів, 19-23 вересня 2011 р.: 301.

ЛоБАЧЕВСьКА О.В. (2011). Репродуктивна стратегія мохоподібних на антропогенно трансформованих територіях. Відновлення порушених природних екосистем: мат-ли IV міжнар. наук. конф., Донеиьк, 18-21 жовтня 2011 р.: 219-220.

ЛоБАЧЕВСьКА О.В. (2012). Мохоподібні породних відвалів Червоноградського гірничопромислового району. Чорноморськ. бот. ж., 8 (1): 67-77.

ЛОБАЧЕВСьКА О.В. (2012). ВПлив мохоподібних на кислотність та вміст вологи у верхньому шарі техногенного грунту. Рекультивація складних техноекосистем y новому тисячолітті: ноосферний аспект: міжнар. наук.-практ. конф.: зб. мат-лів, Дніпропетровськ, 29-30 травня 2012 p.: 235-237.

ЛоБАЧЕВСьКА О.В. (2012). Репродуктивна стратегія мохоподібних на девастованих територіях видобутку сірки (Львівська область). Укр. бот. журн., 69 (3): 406-416.

ЛОБАЧЕВСьКА О.В. (2012). Сезонні зміни пігментного комплексу Ceratodon purpureus (Hedw.) Brid. в умовах техногенно трансформованих територій. IV відкритий з ’̈зд фітобіологів Причорномор'я, присвячений ювілею проф. М.Ф. Бойка: Зб. тез доп., Херсон, 19 січня 2012 р.: 16.

ЛОБАЧЕВСКАЯ О.В. (2013). Особенности клеточного наследования способности к апогамии у мха Tortula modica R.H. Zander. Инновационные направления современной физиологии растений: мат-ль Всероссийской науч. конф. с междунар. участием, Москва, 2-6 июня 2013 2.: 71-72.

ЛоБАЧЕВСьКА О.В. (2013). Морфологічні особливості безстатевих репродуктивних органів мохоподібних. Сучасна фітоморфологія: мат-ли 2-ї міжнар. наук. конф., Львів, 14-16 травня 2013 р.: 253266.

ЛоБАчевСьКА О.В. (2013). Регенераційна здатність спор та діаспор Bryum argenteum Hedw. в різних умовах водного і температурного режимів. V відкритий з'їз фітобіологів Причорномор'я: зб. тез доп., Херсон, 25 квітня 2013 р.: 23.

ЛоБАЧЕВСьКА О.В. (2013). Фенотипна пластичність Ceratodon purpureus Hedw. в умовах техногенно змінених територій. Рослини та урбанізація: мат-ли III Міжнар. наук.-практ. конф., Дніпропетровськ, 19-20 березня 2013 р.: 101-104.

ЛОБАЧЕВСьКА О.В. (2014). Гравічутливість в онтогенезі мохів. 14-та українська конференція з космічних досліджень: зб. мат-лів, Ужгород, 2-8 вересня 2014 р.: 66.

ЛОБАЧЕВСьКА О.В. (2014). Мохоподібні як модель дослідження екофізіологічної адаптації до умов природного середовища. Чорноморськ. бот. ж., 10 (1): 48-60.

ЛОБАЧЕВСьКА О.В. (2015). Особливості акумуляції та перерозподілу важких металів між субстратом і рослинами Ceratodon purpureus (Hedw.) Brid. в умовах техногенного забруднення. VI відкритий з '̈зд фітобіологів Причорномор'я: мат-ли наук. конф., Херсон, 19 травня 2015 р.: 36-38.

ЛОБАЧЕВСЬКА О.В., БОЙКО I.В. (2014). Сезонні зміни міцності зв’язку пігмент-білкових комплексів і спектрів поглинання фотосинтетичних пігментів у мохів залежно від умов місцезростань на техногенно порушених територіях. Інтродукція, збереження та моніторинг рослинного різноманіття: матеріали Міжнар. наук. конф., присвяченій 175-річчю Ботанічного саду імені 
акад. О.В. Фоміна Київського нач. ун-ту ім. Тараса Шевченка, Київ, 20-24 травня 2014 р.: 191-192.

ЛОБАЧЕВСьКА О.В., БОЙКО І.В. (2015). Морфофізіологічні пристосування мохів Funaria hygrometrica i Brachythecium glareosum (Bryophyta) до періодичного висушування. Укр. бот. журн., 72 (6): 658-663.

ЛОБАЧЕВСЬКА О.В., РАБИК І.В. (2012). Особливості вегетативного розмноження мохоподібних на відвалах сірчаного видобутку. Вісник Львівського ун-ту. Серія біологічна, 60: 75-88.

ЛОБАЧЕВСьКА О.В., РАБИК І.В. (2015). Бріологічний гербарій Інституту екології Карпат НАН України. Вісник Харківського наи. ун-ту імені В.Н.Каразіна. Серія: біологія, 25 :64-71

ЛОБАЧЕВСКАЯ О.В., БАРАНОВ В.И., КАРПИНЕЦ Л.И. (2015). Участие бриофитов в восстановительных процессах субстратов породных отвалов угольных шахт. Проблемы рекультивации отходов быта, промышленного и сельскохозяйственного производства: материалы IV Междунар. науч. эколог. конф., ч.2. Краснодар: 440-442.

ЛОБАЧЕВСЬКА О.В., БОЙКО І.В., КАРПІНЕЦЬ Л.І. (2014). ФенотиПна пластичність моху Ceratodon purpureus (Hedw.) Brid. в умовах техногенно трансформованого середовища. Біологічні студіï, 8 (3): 5-16.

ЛОБАЧЕВСЬКА О.В., КАРПІНЕЦЬ Л.І., ОКСЕНЮК У.А. (2015). Участь мохів у відновЛенні девастованих територій видобутку вугілля. Екологічна безпека як основа сталого розвитку суспільства. Свропейський досвід і перспективи: мат-ли II Міжнар. наук.-практич. конф., Львів, 4-6 листопада 2015 р.: 77-79.

ЛОБАЧЕВСЬКА О.В., ХОРКАВЦІВ Я.Д., КИЯК Н.Я. (2015). Участь гравітації у вегетативному розмноженні мохів. 15-а украӥнська конференція з космічних досліджень: тези доп. конф., Одеса, 24-28 серпня 2015 р.: 46.

ЛОБАЧЕВСьКА О.В., ХОРКАВЦІВ Я.Д., КИЯК Н.Я., КІт Н.А., ДАНИЛКІВ І.С. (2015). Гравіморфогенез гаметофіту мохів. Космічна наука і технологія, 21 (6): 94-102.

МАКАРЦОВА Е.А., МАШТАЛЕР А.В. (2012). Жизненные формы мохообразных селитебных территорий Луганской области. Актуальні проблеми ботаніки та екології: Мат-ли міжнар. конф. молодих вчених, Ужгород, 19-23 вересня 2012 р.: 35-36.

МАмчур 3.І., БІЛьсьКА І.Я. (2012). Епіфітні мохоподібні центральної частини міст Львова та ІваноФранківська. Роль природоохоронних установ у збереженні біорозмаїття, етнокультурної спадщини та збалансованому розвитку територій: мат-ли міжнар. наук.-практ. конф., присвяченої 10-річчю НПП «Гуиульщина», Косів, 18-19 травня 2012 р.: 170-174.

МАмЧУР 3., БІЛЬСЬКА І. (2013). Особливості епіфітних бріофітів в умовах урбоекосистем. Вісник Львівського ун-ту. Сер. біологічна, 61: 125-132.

МАмчур 3., ХмІль Т. (2011). Бріологія у Львівському університеті. IV відкритий з їз фітобіологів Причорномор'я: зб. тез доп., Херсон, 19 січня 2011 р.: 18.

МАмчур 3.I., ЧуБА М.В. (2015). Антоцероти і печіночні мохи Волинського Полісся. Стан $i$ біорізноманіття екосистем Шацького національного природного парку: мат-ли наук. конф., Львів, 10-13 вересня 2015 р.: 59-61.

Мамчур 3., ЧуБА М., МАмчУр А. (2015). Маршанціофіти Чорногори (Українські Карпати). Iсторичні $i$ сучасні аспекти вивчення біоти Kарпат: мат-ли наук. конф., присвяченої 60-річчю Високогірного біологічного стаціонару Львівського нац. ун-ту ім. Івана Франка, Львів, 27-30 липня 2015 р.: 44-45.

МАРИСКЕВИЧ О.Г., ШПАКІВСЬКА І.М., КАГАЛО О.О., КОЗЛОВСЬКИЙ В.І., РАБИК В.І. (2014). ОсоблИвості відновлення грунтового та рослинного покриву на територіях підземної виплавки сірки на прикладі Немирівського родовища (Яворівський район, Львівська область). Наукові основи збереження біотичної різноманітності, 5 (12): 17-32.

МАШТАЛЕР А.В., МАКАРЦОВА Е.А. (2011). Особенности произрастания и распространения мхов на территории пгт. Боровское Луганской области. Фундаментальне и прикладне исследования в биологии: Мат-ль II Междунар. науч. конф. студентов, аспирантов и молодых ученых, Донеиьк, 19-22 сентября 2011 г.: 27-28.

МАШТАЛЕР А.В., МАКАРЦОВА Е.А. (2012). Видовой состав и особенности произрастания мохообразных на селитебных территориях Луганской области. Проблеми екології та охорони природи техногенного регіону, 1 (12): 97-101.

МЕЛьник I.В. (2011). Окисний стрес і стан антиоксидантної системи в гаметофорах моху Funaria hygrometrica Hedw. за впливу пероксиду водню, іонів важких металів та екзогенного кальцію. Відновлення порушених природних екосистем: мат-ли IV міжнар. наук. конф., Донецьк, 18-21 жовтня 2011 р.: 243-245.

МЕЛЬНИК І.В., ЛОБАЧЕВСЬКА О.В. (2011). Градієнтний розподіл іонів кальцію у протонемі моху Funaria hygrometrica Hedw. Стан і біорізноманіття екосистем Шацьккого національного природного парку: мат-ли наук. конф., Шацьк, 8-11 вересня 2011 р.: 59.

НиПОРКО С.О., ПАРТИКА Л.Я. (2011). Анотований список мохоподібних гранітних каньйонів України. Лишайники, мохоподібні та наземні водорості гранітних каньйонів Украӥни. Київ, 2011. С. 
324-347.

НИПОРКО С.О., ПАРТИКА Л.Я. (2011). Мохоподібні. Лишайники, мохоподібні та наземні водорості гранітних каньйонів Украӥни. Київ, 2011. С. 57-64, 138-144.

ПАРТИКА Л.Я. (2015). Академік Дмитро Костьович Зеров (до 120-річчя від дня народження). Укр. бот. журн., 72 (6): 610-618.

ПАРТИКА Л.Я. (2011). Дмитро Костьович Зеров (1895-1971). Інститут ботаніки ім. М.Г. Холодного НАН України (1921-2011). Віхи історї̈ та сучасність: 394-395.

ПАРТИКА Л.Я., ВІРЧЕНКО В.М., ОРЛОВ О.О. (2013). Мохоподібні Поліського природного заповідника. Фіторізноманіття Поліського природного заповідника: водорості, мохоподібні, судинні рослини: 97-127.

ПІкулик Л., РАГУЛІнА М. (2013). Мохоподібні (Bryobionta) скельних виходів урочища Бубнище (Сколівські Бескиди). Біологічні Студї, 7 (3): 189-196.

РАБИК І.В., ДАНИЛКІВ І.С. (2013). Особливості біоморфологічної структури бріофітного покриву сірчаних відвалів. Наукові основи збереження біотичної різноманітності, 4 (11): 123-130.

РАБИК І.В., ЩЕРБАЧЕНКО О.І., ДАНИЛКІВ І.С. (2011). ВПлив бріофітного покриву на зволоженість техногенних субстратів сірчаних родовищ. Відновлення порушених природних екосистем: Мат-ли IV Міжнар. наук. конф., Донецьк, 18-21 жовтня 2011 р.: 318-320.

РАБИК I.В., ЩЕРБАЧЕНКО О.І., ДАНИЛКІВ I.C. (2011). Участь мохоподібних у відновленні рослинного покриву на територіях підземної виплавки сірки Язівського родовища. Наукові записки Тернопільського дер. пед. ун-ту ім. Володимира Гнатюка. Серія: Біологія, 2 (47): 120-124.

РАБИК І.В., ЩЕРБАЧЕНКО О.І., ДАНИЛКІВ І.С. (2012). Аналіз динаміки бріофітного покриву на території підземної виплавки сірки Немирівського родовища. IV відкритий з'їзд фітобіологів Причорномор'я, присвячений ювілею професора М.Ф. Бойка: Зб. тез доп., Херсон, 19 січня $2012 p .: 21$.

РАБИК І.В., ЩЕРБАЧЕНКО О.І. ДАНИЛКІВ І.С. (2013). Аналіз репродуктивного зусилля мохів залежно від умов місцезростань на територіях сірчаного видобутку. Рослини та урбанізація: мат-ли III Міжнар. наук.-практич. конф., Дніпропетровськ, 19-20 березня 2013 р.: 68-70.

РАБИК И.В., ЩЕРБАЧЕНКО О.И., ДАНИЛКИВ И.С. (2015). Роль бриофитного покрова в восстановлении девастированных территорий добычи серы. Бриология: традиции и современность: Сб. статей по мат-лам Междунар. бриолог. конф., посвященной 100-летию со дня рождения А. Л. Абрамовой, Российская Федерация, Санкт-Петербург, 12-16 октября 2015 г.: 125-129.

РАБИК І.В., ДАНИЛКІВ І.С., ЩЕРБАЧЕНКО О.І., КІт Н.А. (2012). Сезонна динаміка бріофітного покриву на відвалі сірчаного видобутку. Чорноморськ. бот. ж., 8 (1): 77-86.

РАБИК І.В., ЛОБАЧЕВСЬКА О.В., ЩЕРБАЧЕНКО О.І., ДАНИЛКІВ І.С. (2015). Стан бріофітного покриву залежно від умов ревіталізації посттехногенних територій. VI відкритий з'їзд фітобіологів Причорномор'я: мат-ли наук. конф., Херсон, 19 травня 2015 р.: 40-42.

РАГУліна M.Є. (2011). Мохоподібні (Bryobionta) парку імені Івана Франка (м. Львів). Старовинні парки $i$ ботанічні сади - наукові центри збереження біорізноманіття рослин та охорони історикокультурної спадщини: м-ли міжнар. наук. конф., Умань, 6-8 жовтня 2011 р.: 185-188.

РАГУлІна М.Є. (2011). Мохоподібні (Bryobionta) старих парків Південного Криму. Заповедники Крымма. Биоразнообразие и охрана природы в Азово-Черноморском регионе: м-ль VI Междунар. науч.практ. конф., Симферополь, 20-22 октября 2011 р.: 224-229.

РАГУлІна M.С. (2012). Syntrichia laevipila Brid. - новий синантропний вид моху для флори України. IV відкритий з '̈зд фітобіологів Причорномор'я, , присвячений ювілею професора М.Ф.Бойка: $3 б$. тез доп., Херсон, 19 січня 2012 р.: 20.

РАГУлІна М.С. (2012). Водні та навколоводні бріоугруповання старовинних парків Південного Криму. Биоразнообразие и устойчивое развитие: тезисы II Междунар. науч.-практ. конф, Симферополь, 12-15 сентября 2012 г.: 111-113.

РАГУлІна М.Є. (2012). Мохоподібні (Bryobionta) старих дерев Південнобережжя Криму. Дендрологія, квітникарство та садово-паркове будівництво: м-ли міжнар. наук. конф., Ялта, 5-8 червня 2012 p.: 58.

РАГУлІна М.С. (2012). Постпірогенна сукцесія мохового покриву у Шацькому національному парку. Роль природоохоронних установ у збереженні біорозмаїття, етнокультурної спадщини та збалансованому розвитку територій: м-ли міжнар. наук.-практ. конф., Косів, $18-19$ травня 2012 p.: 206-208.

РАГуліна М.С. (2012). Сукцесії мохового покриву на техногенних піщаних відслоненнях ВолиноПоділля. Наукові записки Держ. природознавчого музею НАНУ, 28: 63-68.

РАГУлІна М.Є. (2013). Рідкісні та нові для Розточчя-Опілля види синантропних мохоподібних в епіфітних обростаннях Leucodontetalia sciuroidis v. Hübschm. 1952. V відкритий з'їд фітобіологів Причорномор'я: зб. тез доп., Херсон, 25 квітня 2013 р.: 25. 
РАГУЛІнА М.Є. (2015). Участь мохоподібних у процесах самовідновлення техногенно порушених екосистем Волино-Поділля та Передкарпаття: Автореф. дис. ...канд. біол. наук. Львів, 2015. $20 \mathrm{c}$.

РАГУЛІнА М.С. (2015). Бріофлора кар’єрів глиняної сировини рівнинної частини Львівської області. Зап. держ. природозн. музею, 31: 107-112.

РАГУЛІНА М.С., ІСІКОВ В.П. (2012). Syntrichia laevipila Brid. - новий вид моху для флори України. Чорноморськ. бот. ж., 8 (2): 241-244.

РАГУЛІНА М.С., ІСІКОВ В.П. (2013). Доповнення до бріофлори заповідника «Мис Мартьян». Наукові записки природного заповідника «Мис Мартьян» (за матеріалами міжнар. наук. конф. «40 лет природному заповеднику «Мыс Мартьян», Ялта, 14-17 травня 2013 р.: 146.

РАГУЛІна М.Є., ІсІКОВ В.П. (2011). Мохоподібні (Bryobionta) настінних обростань Великої Ялти. Бюл. держ. Нікітського ботанічного саду, 103: 20-24.

РАГУЛІНА М.С., ІСІКОВ В.П. (2012). Епіфітні бріоугруповання старовинних парків Південного берега Криму. Бюл. держ. Нікітського ботанічного саду, 105: 21-24.

РАГУЛІнА М.Є. ОрЛОв О.Л. (2011). Мохоподібні (Bryophyta) як агенти ініціального грунтоутворення в техногенних екосистемах. Наукові записки Державного природознавчого музею, 27: 89-94.

РІПЕЦЬКИЙ Р.Т., КИт Н.А. (2011). Влияние микрогравитации на рост протонемы и образование почек гаметофоров у мха Pottia intermedia. Актуальные проблемы космической биологии и медицины: Космический форум 2011, Москва, 18-21 октября 2011 г.: 184.

РІПЕЦЬКИЙ Р.Т., ХОРКАВЦІВ Я.Д. (2012). Епігенетична адаптація мохів і феномен клітинної пам'яті. Укр. бот. журн., 69 (2): 302-314.

СИЧАК Н., КАГАЛО О., РАБИК І., КОПЛИК О. (2011). Гербарій Інституту екології Карпат НАН України. Гербарії України. Index Herbariorum Ucrainicum. Київ, 2011. С. 173-179.

Соханьчак P.P. (2011). Вплив моху Campylopus introflexus (Hedw.) Brid. на процеси первинного грунтотворення на шахтних відвалах. Стан $i$ біорізноманіття екосистем Шацького національного природного парку: мат-ли наук. конф., Шацьк, 8-11 вересня 2011 р.: 100-101.

СОХАНЬЧАК Р.P. (2011). Сезонні зміни вмісту фотосинтетичних пігментів моху Campylopus introflexus (Hedw.) Brid. 3 різних місцезростань шахтного відвалу. Актуальні проблеми ботаніки та екології: мат-ли міжнар. конф. молодих учених, Березне, 9-13 серпня 2011 р.: 202-203.

СОХАНЬЧАК Р.P. (2011). Особливості накопичення макро - та мікроелементів у гаметофорах моху Campylopus introflexus (Hedw.) Brid на породах шахтного відвалу. Відновлення порушених природних екосистем: мат-ли IV міжнар. наук. конф., Донецьк, $18-21$ жовтня 2011 р.: 339341.

СОхАНЬЧАК P.P. (2012). Сезонні зміни пігментного комплексу Campylopus introflexus (Hedw.) Brid. залежно від мікрокліматичних умов на відвалі шахти «Надія» (Львівська обл.). Наукові основи збереження біотичної різноманітності: мат-ли ХІ наук. конф. молодих учених, Львів, 24-25 травня 2012 р.: 207-208.

СОхАНьчАК Р.P. (2012). Вміст білків, жирів та розчинних вуглеводів у гаметофіті моху Campylopus introflexus (Hedw.) Brid. за росту на шахтному відвалі. Стан і біорізноманіття екосистем Шацького національного природного парку: матер. наук. конф. Шацьк, 6-9 вересня 2012 р.: 67-68.

СОхАНьЧАК Р.P. (2013). Нові види мохів (Bryophyta) на відвалах вугільних шахт Червоноградського гірничопромислового району. Стан $і$ біорізноманіття екосистем Шацького національного природного парку: мат-ли наук. конф., Шацьк, 12-15 вересня 2013 р.: 73-74.

СОХАНЬЧАК Р.Р. (2014). Сезонна динаміка вмісту фенолів і активності поліфенолоксидази в гаметофіті моху Campylopus introflexus (Hedw.) Brid. за умов росту на субстратах шахтних відвалів і торфокар'єрів. Перспективы интродукиии декоративных растений в ботанических садах и дендропарках: мат-ль Междунар. науч. конф., Симферополь, 23-26 сентября 2014 г.: $193-$ 196.

СОХАНЬЧАК Р.Р. (2014). Зміни вмісту фенольних сполук та активності поліфенолоксидази у гаметофіті моху Campylopus introflexus (Hedw.) Brid. за росту на субстратах відвалу шахти «Надія» та торфокар'єрів (Львівська обл.). Стан і біорізноманіття екосистем Шацького природного парку: мат-ли наук. конф., Шацьк, 11-14 вересня 2014 р.: 79-81.

СОхАНьЧАК P.Р. (2015). Мінливість вегетативних клонів гаметофіту моху Campylopus introflexus (Hedw.) Brid. за впливу іонів кадмію та свинцю. Стан $i$ біорізноманіття екосистем Шацького національного природного парку: мат-ли наук. конф., Шацьк, 10-13 вересня 2015 р.: 98-99.

СОХАНьЧАК Р.Р. (2015). Мінливість морфометричних показників, оводненості гаметофіту та ступеня розкладу мохових дернин Ceratodon purpureus i Campylopus introflexus залежно від умов антропогенно змінених територій Львівщини. Наукові основи збереження біотичної різноманітності: мат-ли I (ХІІ) Міжнар. наук. конф. молодих учених, Львів, 21-22 травня 2015 p.: 206-208. 
СОХАНЬЧАК Р.Р., БЕШЛЕЙ С.В. (2014). Сезонні зміни міцності хлорофіл-білкових комплексів та спектрів поглинання пігментів моху Campylopus introflexus (Hedw.) Brid. залежно від мікрокліматичних та едафічних умов техногенно змінених територій. Відновлення порушених природних екосистем: мат-ли V Міжнар. наук. конф., Донеиьк, 12-15 травня 2014 р.: 400-402.

СОХАНЬЧАК Р.Р., ЛОБАЧЕВСЬКА О.В. (2012). Особливості вПливу моху Campylopus introflexus (Hedw.) Brid. на відновлення техногенних субстратів шахтних відвалів. Біологічні Студї, 6 (1): 101108.

СОХАНЬЧАК Р.Р., ЛОБАЧЕВСЬКА О.В., БЕШЛЕЙ С.В. (2013). Сезонні зміни У пігментному комплексі моху Campylopus introflexus (Hedw.) Brid. на вершині відвалу шахти «Надія». Вісник Львівського унту. Серія біологічна, 62: 180-187.

ТАСєНКЕВИЧ Л.О., МАМЧУР 3.І., ХМІЛЬ Т.С., ЖУК О.О. (2013). Іменні колекції ХІХ-ХХ століть у Гербарії Львівського національного університету імені Івана Франка. Вісник Львівського ун-ту. Серія біологічна, 65: 112-120.

ФІНЮК Н.С., ЧАПЛЯ А.С., МІТІНА Н.Є., БОЙКО Н.М., ЛОБАЧЕВСЬКА О.В., М'ЯГКОТА О.С., СМЕЦЬ А.І., БЛЮМ Я.Б., ЗАІчЕНКО О.С., СТОЙКА Р.С. ФІНЮК Н.С. (2014). Генетична трансформація моху Ceratodon purpureus за допомогою нових полікатіонних носіїв ДНК. Цитология и генетика, 48 (6): 3-10.

ХмІль Т.С., МАмчУР 3.І., КОНДРАТЮК С.Я. (2013). Колекція мохів Антона Ремана з Південної Африки в гербарії Львівського національного університету імені Івана Франка (LW). Львів: ЛНУ імені Івана Франка, 2013. 134 с.

ХоДосовЦЕВ О.Є., БОЙКО М.Ф. (2013). Лишайникові та мохові угруповання Чорноморського біосферного заповідника (Івано-Рибальчанська ділянка). Природничий альманах: 44-56 .

ХодосовцЕВ О.С., БойКО М.Ф. (2012). Лишайникові та мохові угруповання у фітоценології. Популяційна екологія рослин: сучасний стан, точки росту: зб. наук. працьь за мат-ми міжнар. інтернетсимпозіуму, Суми, 2-4 квітня 2012 р.: 78.

ХОДОСОВЦЕВ О.Є., БОЙКО М.Ф., НАДЕІНА О.В., ХОДОСОВЦЕВА Ю.А. (2011). Лишайникові та мохові угруповання нижньодніпровських арен: синтаксономія та індикація дефляційних процесів. Чорноморськ. бот. ж., 7 (1): 44-66.

ХОРКАВЦІВ Я.Д. (2011). Особливості стійкості мохів до ртуті. Відновлення порушених природних екосистем: мат-ли IV міжнар. наук. конф., Донецьк, 18-21 жовтня 2011 р.: 383-385.

Хоркавцив Я.Д., Кит Н.А. (2013). Гравизависимая поляризация спор мха Ceratodon purpureus Brid. Инновационные направления современной физиологии растений: мат-лы Всероссийской науч. конф. с междунар. участием, Москва, 2-6 июня 2013 г.: 99-100.

ХОРКАВЦІВ Я.Д., КІт Н.А. (2013). Про стійкість проростання спор і регенерації листків мохів до сполук ртуті та сірки. Укр. бот. журн., 70 (1): 81-90.

ХОРКАВцІВ Я.Д., КІт Н.А. (2014). Про стійкість спор мохів до стресових чинників. Укр. бот. журн., 71 (4): 69-78.

ХОРКАВЦІВ Я.Д., ЛОБАЧЕВСЬКА О.В. (2011). Особливості генеративного розмноження домінантного виду Barbula unguiculata Hedw. на відвалах сірчаного видобутку. Наукові записки Тернопільського держ. пед. ун-ту ім. Володимира Гнатюка. Серія: Біологія, 2 (47): 150-155.

ХОРКАВцІВ Я.Д., ЛОБАЧЕВСьКА О.В. (2011). Регуляція толерантності мохів до водного дефіциту. Регуляція росту і розвитку рослин: фізіолого-біохімічні та генетичні аспекти: мат-ли 2-ої міжнар. конф., Харків, 11-13 жовтня 2011 р.: 128-129.

ХОРКАВЦІВ Я.Д., РІПЕЦЬКИЙ Р.Т. (2011). Про природу стійкості спор мохів до стресових впливів. III з '̈̈зд Укр. ботан. тов-ва: мат-ли з 'ізду, Львів, 19-23 вересня 2011 р.: 335.

ХОРКАВЦІВ Я.Д., ЛОБАчЕВСЬКА О.В., ДАНИЛКІВ І.С. (2014). До 80-річчЯ професора, доктора біологічних наук Ореста Теодоровича Демкова. Укр. бот. журн., 71 (3): 90-93.

ХОРКАВЦІВ Я.Д., РАБИК І.В., ДАНИЛКІВ І.С. (2012). Аналіз видового складу мохоподібних на території нафтових родовищ м. Борислава. Чорноморськ. бот. ж., 2 (9): 195-204.

ХОРКАВцІВ Я.Д., РАБИК І.В., ДАНИЛКІВ І.С. (2012). Мохоподібні нафтового родовища м. Борислава: особливості толерантності. Чорноморськ. бот. ж., 2 (8): 195-204.

ХОРКАВЦІВ Я.Д., КИЯк Н.Я., КІт Н.А. (2014). Гравізалежний морфогенез мохів. 14-та укр. конф. $з$ космічних досліджень, Ужгород, 2-8 вересня, 2014 р.: 71.

ХОРКАВцІв Я.Д., КИЯк Н.Я., КІт Н.А. (2015). Роль ауксину в гравііндукції галуження клітин протонеми мохів. 15-а українська конференція з космічних досліджень: тези доп. конф., Одеса, 24-28 серпня 2015 р.: 54.

ХОРКАВЦІВ Я.Д., КОРДЮМ С.Л., ЛОБАЧЕВСьКА О.В., КИЯК Н.Я., КІТ Н.А. (2015). Галуження клітин протонеми Ceratodon purpureus Brid. в умовах зміненої сили тяжіння. Укр. бот. журн., 72 (6): 671-676.

ЧАПЛЯ А.С., ФІНЮК Н.С., БОЙКО Н.М., МІтІНА Н.С., ЛОБАЧЕВСЬКА О.В., ЗАІЧЕНКО О.С., СТОЙКА Р.С. (2013). Генетична трансформація моху Ceratodon purpureus новими поліамфолітними носіями. Стан і біорізноманіття екосистем Шацького національного природного парку: мат-ли наук. конф., Шацьк, 12-15 вересня 2013 р.: 86-87. 
ШАПОШНІКОВА А.О., БОЙКО М.Ф., МоЙсІєНКО І.І., МЕЛЬНИК Р.П., ПОНОМАРЬОВА А.А. (2015). Матеріали до проектованих ботанічних заказників (Херсонська область, Україна). Чорноморськ. бот. ж., $11(3): 346-363$.

ШИЯН Н.М., ДУДКА І.О., КОНДРАТЮК С.Я., ЦАРЕНКО П.М., ВІРЧЕНКО В.М., БЕЗУСЬКО Л.Г. (2011). Гербарій Інституту ботаніки ім. М.Г. Холодного НАН України - Національний гербарій України. Інститут ботаніки ім. М.Г. Холодного НАН Украӥни (1921-2011). Віхи історії та сучасність: 305-324.

ШИЯН Н.М., ДУДКА І.О., КОНДРАТЮК С.Я., ЦАРЕНКО П.М., ВІРЧЕНКО В.М., БЕЗУСЬКО Л.Г. (2012). Національному гербарію України 90 років. Укр. бот. журн., 69 (1): 77-87.

ЩЕРБАЧЕНКО O.I. (2012). Вплив важких металів на вміст пігментів фотосинтезу у моху Drepanocladus aduncus (Hedw.) Warnst. Наукові основи збереження біотичної різноманітності: Мат-ли одинадиятої наук. конф. молодих учених, Львів, 24-25 травня 2012 р.: 229.

ЩЕРБАЧЕНКО О.І. (2012). ВПлив іонів важких металів на ростові та фізіолого-біохімічні реакції піщаних і водних культур моху Drepanocladus aduncus (Hedw.) Warnst. Біологічні Cmyдіï, 6 (2): 89-97.

ЩЕРБАЧЕНКО O.I. (2012). Особливості накопичення і розподілу іонів важких металів у клітинах моху Drepanocladus aduncus (Hedw.) Warnst. Чорноморськ. бот. ж., 8 (2): 189-194.

ЩЕРБАЧЕНКО O.I. (2013). Природа толерантності моху Drepanocladus aduncus (Hedw.) Warnst. до впливу важких металів. Наукові основи збереження біотичної різноманітності, 4 (11): 181-196.

ЩЕРБАЧЕНКО O.I. (2013). Нагромадження важких металів і реакції моху Drepanocladus aduncus (Hedw.) Warnst. на їх токсичну дію: автореф. дис. ... канд. біол. наук : спец. 03.00.12 - «Фізіологія рослин». Львів: 2013. 20 с.

ЩЕРБАЧЕНКО O.I. (2014). Важкі метали як токсичний фактор забруднення природного середовища. Стійкість і адаптація рослин до їх впливу. Наукові записки державного природознавчого музею, 30: 157-182.

ЩЕРБАЧЕНКО О.I. (2014). Толерантність мохів Bryum argenteum Hedw. і Funaria hygrometrica Hedw. 3 різною життєвою стратегією із фонових і антропогенно трасформованих територій до водного дефіциту. Інтродукція, збереження та моніторинг рослинного різноманіття: мат-ли міжнар. наук. конф., присвяченої 175-річчю Ботанічного саду імені акад. О.В. Фоміна Київького нач. ун-ту ім. Тараса Шевченка, Київ, 20-24 травня 2014 р.: 218-219.

ЩЕРБАЧЕНКО O.I. (2014). Толерантність мохів з різними життєвими стратегіями із фонових і порушених територій вугільного видобутку до впливу важких металів. Стан і біорізноманіття екосистем Шацького природного парку: мат-ли наук. конф., Шацьк, 11-14 вересня 2014 р.: 103-104.

ЩЕРБАЧЕНКО О.І. (2015). Особливості стійкості мохів із територій видобутку вугілля до впливу важких металів. VI відкритий з'їзд фітобіологів Причорномор'я: Зб. мат-лів доп., Херсон, 19 травня 2015 p.: 45-46.

ЩЕРБАЧЕНКО O.I., ДЕМКІВ О.T. (2013). Толерантність моху Drepanocladus aduncus (Hedw.) Warnst. i його адаптація до впливу іонів свинцю. Физиология растений и генетика, 45 (4): 227-333.

Щербаченко O.I., Щербаченко T.M. (2014). Перспективність використання моху Drepanocladus aduncus (Hedw.) Warnst. для бріоіндикації та фіторемедіації. Відновлення порушених природних екосистем: мат-ли V Міжнар. наук. конф., Донеиьк, 12-15 травня 2014 р.: 407-408.

ЩЕРБАЧЕНКО О., ДЕМКІВ О., КОЗЛОВСьКИй В. (2014). Нагромадження і розподіл іонів важких металів у клітинах гаметофіту мохів. Праці Наукового товариства ім. Шевченка. Екологічний збірник, 39: $218-224$.

ЩЕРБАЧЕНКО О.І., РАБИК І.В., ДАНИЛКІВ І.С. (2013). Морфо-фізіологічні параметри моху Drepanocladus aduncus (Hedw.) Warnst. за різних умов водного і температурного режимів на території відвалу сірчаного виробництва. V відкритий з '̈зд фітобіологів Причорномор'я: зб. тез доп., Херсон, 25 квітня 2013 р.: 29.

ЩЕРБАЧЕНКО О.І., РАБИК І.В., ЛОБАЧЕВСьКА О.В. (2015). Участь мохоподібних у ренатуралізації девастованих територій Немирівського родовища сірки. Укр. бот. журн., 72 (6): 596-602.

ЩЕРБАЧЕНКО О.І., РАБИК І.В., КІт Н.А. (2012). ВПлив мохів на водний і температурний режим субстрату відвалу сірчаного видобутку. IV відкритий з 'їзд фітобіологів Причорномор'я, присвячений ювілею професора М.Ф. Бойка: 3б. тез доп., Херсон, 19 січня 2012 р.: 25.

BARSUKOV O.O. (2013). Bryophyte species diversity in the «Dvorichanskyi» Nature Reserve and adjacent areas. Актуальні проблеми ботаніки та екології : мат-ли міжнар. конф. молодих учених, Щолкіне, 18-22 червня 2013 р.: 24-26.

BILSKA I., MAMCHUR Z. (2011). Research of western Ukraine Territory. Proceedings of the $V$ intern. young scientists conf. "Biodiversity. Ecology. Adaptation. Evolution.", dedicaded to 160 anniversary from the birth of professor Frants Kamenskiy, June 13-17, 2011: 12.

BILSKA I., MAMCHUR Z. (2015). Taxonomic composition of bryoflora of plain part of Ivano-Frankivsk Oblast. Молодь і поступ біології: зб. тез VIII Міжнародної конф. студентів та аспірантів, Львів, 20 23 квітня 2015 р.: 227-229. 
BoIKo M.F. (2011). Lazarenkia (Pottiaceae, Bryopsida) - new genus of mosses and Lazarenkia kozlovii - new combination at the species rank. Chornomorsk. bot. z., 7 (4): 400-402.

BOIKO M.F. (2011). Syntrichia ruralis var. polysporogonica and Riccia rhenana var. violacea - news varietas bryophytes. Chornomorsk. bot. z., 7 (1): 92-93.

BoIKO M.F. (2012). Incertophylity as adaptive strategies of bryophytes. International bryological conference dedicated to 100 year anniversary of R.N.Schljakov: Abstracts. Apatity, Murmansk Province, 24-26th June 2012: 17-18.

BOIKO M.F. (2014). The Second checklist of Bryobionta of Ukraine. Chornomors 'k. bot. z., 10 (4): $426-487$.

Boiko M.F., Khodosovtsev O.Ye., Gavrylenko L.M., MelnyK R.P., Klymenko V.M., Shaposhnikova A.O. (2015). Phytodiversity and Lichenodiversity in the Conditions of Agricultural Landscapes in Southern Ukraine. Science and Education. Natural and Technical Sciences, 3 (5): 11-14.

BOIKO M.F., KOMISAR O. (2015). Heav metals in gametophytes of moss Bryum caespiticium Hedw. in parks and on Lenina Avenue in Mykolayiv city (Ukraine). Science and Education. Natural and Technical Sciences, 3 (5): 7-10.

GAPON S.V. (2011). The classification of sinusial epigenic and eplgeytic bryophyte communities of forest coenosesof forest-steppe zone of Ukraine. Biodiversity Research and Conservation, 23: 71-73.

KHORKAVTSIV YA.D., DEMKIV O.T. (2011). Light-induced reversion gravitropism of the two moss species. Актуальные проблемы космической биологии и медицины: Космический форум 2011, Москва, 18-21 октября 2011 г.: 185.

KHORKAVTSIV YA.D., KIT N.A. (2014). Cravity modulation of the moss Tortula modica branching. The 40th Cospar Scientific Assembly, 2-10 August, 2014, Moscow, Russia. Book of abstracts: 132.

KYYAK N.YA., BAIK O.L. (2012). The role of bryophytes in renewal of devastated territories of sulphur deposits. Биологические системь: : устойчивость, принцииьы и механизмы функционирования: мат-лы IV Всероссийской науч.-практ. конф., Российская Федеращия, Нижний Тагил, 26-29 марта 2012 2.: 68-69.

KYYAK N.YA., BAIK O.L. (2013). Role of the bryophyte cover in accumulation of the biogenic elements in technogenic substrate on the territory of sulphur extraction. Wschodnie partnerstwo - 2013: materialy IX Międzynarodowej naukowo-praktycznej konferencji, Przemyśl, 7-15 września 2013 r.: 3-10.

KYYAK N.Ya. (2014). Gravity-induced buds formation from protonemata apical cells in the mosses. The 40th Cospar Scientific Assembly, 2-10 August, 2014, Moscow, Russia: Book of abstracts: 149.

KYYAK N.YA., BAIK O.L. (2014). Participating of bryophytes in restoration of the devastated territories of sulphur deposits. Wschodnie partnerstwo - 2014: materialy X Międzynarodowej naukowopraktycznej konferencji, Przemyśl, 7-15 września 2014 r.: 6-16.

KYYAK N.YA., BAIK O.L. (2015). Photosynthetic activity of the mosses on the devastated territories of sulphur extraction. Fundamental and applied science - 2015: proceeding of XI International research and practice conference, Sheffield, UK, October 30 - November 7, 2015: 63-70.

LOBACHEVSKA O.V. (2011). Gravisensitivity of new moss species. Актуальные проблемы космической биологии и медицины: Космический форум 2011: зб. мат-лов, Москва, 18-21 октября 2011 г.: 188.

LOBACHEVSKA O.V. (2012). Peculiarities of moss vegetative reproduction on the dumps of sulphur deposits. Биологические системы: устойчивость, принцииьы и механизмы функционирования: мат-ль IV Всероссийской науч.-практ. конф., Российская Федераџия, Нижний Тагил, 26-29 марта 2012 2.: 84-86.

LOBACHEVSKA O.V. (2014). Gravity regulation in tuber-bearing moss Leptobryum pyriforme (Hedw.) Wilson. The 40th Cospar Scientific Assembly, 2-10 August, 2014, Moscow, Russia). Book of abstracts: 156.

RABYK I.W., SHCHERBACHENKO O.I. (2012). Participation bryophytes in natural restoration of devasted territories of sulfur deposits. Рекультивація складних техноекосистем у новому тисячолітті: ноосферний аспект: мат-ли Міжнар. наук.-практ. конф., Дніпропетровськ, 29-30 травня 2012 p.: 366-368.

RABYK I.W., SHCHERBACHENKO O.I. (2015). Role of bryophytes cover in renaturalization of the technogenic substrates of Yaziv sulfur deposit. Екологічна безпека як основа сталого розвитку суспільства. Європейський досвід $i$ перспективи: мат-ли II Міжнар. наук.-практ. конф., Львів, 4-6 листопада 2015 р.: 91-94.

RABYK I.W., DANILKYV I.S., SHCHERBACHENKO O.I. (2012). Variety and dynamics of bryophytes community on the dump of sulfur extraction. Биологические системы: устойчивость, принципь и механизмы функционирования: мат-ль IV Всероссийской науч.-практ. конф., Российская Федерация, Нижний Тагил, 26-29 марта 2012 г.: 92-94.

Ragulina M. (2011). The Bryoflora of Lviv walls. Biodiversity. Ecology. Evolution. Adaptation: Proceeding of the V intern. Young scientists conf., Odessa, 13-15 th of June, 2011: 134.

SHCHERBACHENKO O.I. (2013). Accumulation of heavy metals and moss Drepanocladus aduncus (Hedw.) Warnst. reactions on their toxic effects. Инновационные направления современной физиологии 
растений: мат-ль Всероссийской науч. конф. с междунар. участием, Москва, 2-6 июня 2013 2.: 230 .

SHCHERBACHENKO O.I., RABYK I.W. (2013). Pioneer moss Dicranella cerviculata participates in primary processes of soil formation in the area of underground sulphur smelting of Nemyriv deposits. Актуальні проблеми ботаніки та екологї: Міжнар. конф. молодих учених, Щолкіне, АР Крим, 18-22 червня 2013 р.: 187-188.

SOKHAN'CHAK R.R. (2013). Influence of the moss Campylopus introflexus (Hedw.) Brid. on the optimization of mine dumps' technogenic substrates. Инновационные направления современной физиологии растений: мат-лы Всероссийской науч. конф. с междунар. участием, Москва, 2-6 июня 2013 2.: 231

SOKHAN'CHAK R.R. (2013). Changes in morphometric parameters of moss Campylopus introflexus (Hedw.) Brid. depending on microclimatic conditions of the dump of mine «Nadiia» (Lviv region). Актуальні проблеми ботаніки та екології: мат-ли міжнар. конф. молодих учених, Щолкіне, АР Крим, 18 22 червня 2013 р.: 268-269.

Stebel A., Virchenko V.M., Plasek V., Ochyra R., BednareK-Ochyra H. (2012). Range extension of Orthodicranum tauricum (Bryophyta, Dicranaceae) in Central-East Europe. Polish Botanical Journal, 57 (1): 119-128.

VIRCHENKO V.M., BARSUKOV O.O. (2012). Myrinia pulvinata (Wahlenb.) Schimp. In: Ellis L.T. et al. New national and regional bryophyte records, 30. Journal of Bryology, 34 (1): 47.

VIRCHENKO V.M., OCHYRA R. (2012). Dichelyma capillaceum (Dicks.) Myrin. In: Ellis L.T. et al. New national and regional bryophyte records, 33. Journal of Bryology, 34 (4): 282-283.

Zubel R., DANYlKIV I., RABYK I., LOBACZEVs'KA O., SOROCA M. (2015). Bryophytes of the Roztocze region (Poland and Ukraine). Maria Curie-Sklodowska University. Lublin, 2015. 145 p.

Zubel R., Danylkiv I., Rabyk I., Lobaczevs'Ka O., Soroca M. (2015). Świat roślin - Mszaki. 3. Świat roślin, grzybów, śluzowców i porostów na Roztoczu. Roztocze. Przyroda i człowiek. Zwierzyniec: $153-159$.

Рекомендує до друку

Отримано 28.02.2017

Ходосовцев О.Є.

Aдреси авторів:

М.Ф. Бойко

Херсонський державний університет

вул. Університетська, 27

Херсон 73000

Украӥна

e-mail:mikhailb@i.ua

B.M. Вірченко

Інститут ботаніки ім. М.Г. Холодного

НАН України

вул. Терещценківська, 2

Київ 01601

Україна

O.В. Лобачевська

Інститут екології Kapnam

НАН України

вул. Стефаника, 11

Львів 79000

Україна
Author's address:

M.F. Бойко

Kherson State University

27, Universytetska Str.

Kherson 73000

Ukraine

e-mail:mikhailb@i.ua

V.M. Virchenko

M.G.Kholodny Institute of Botany NAS of Ukraine

2, Tereshchinkivska Str.

Kyiv 01601

Ukraine

O.V. Lobachevska

Institute of Ecology of the Carpathians, NAS

of Ukraine

11, Stephanyka Str.

Lviv 79000

Ukraine 